Pacific Northwest Laboratory

Annual Report for 1983 to the DOE Office of the Assistant Secretary for Environmental Protection, Safety and Emergency Preparedness

Part 5 Overview and Assessment February 1984

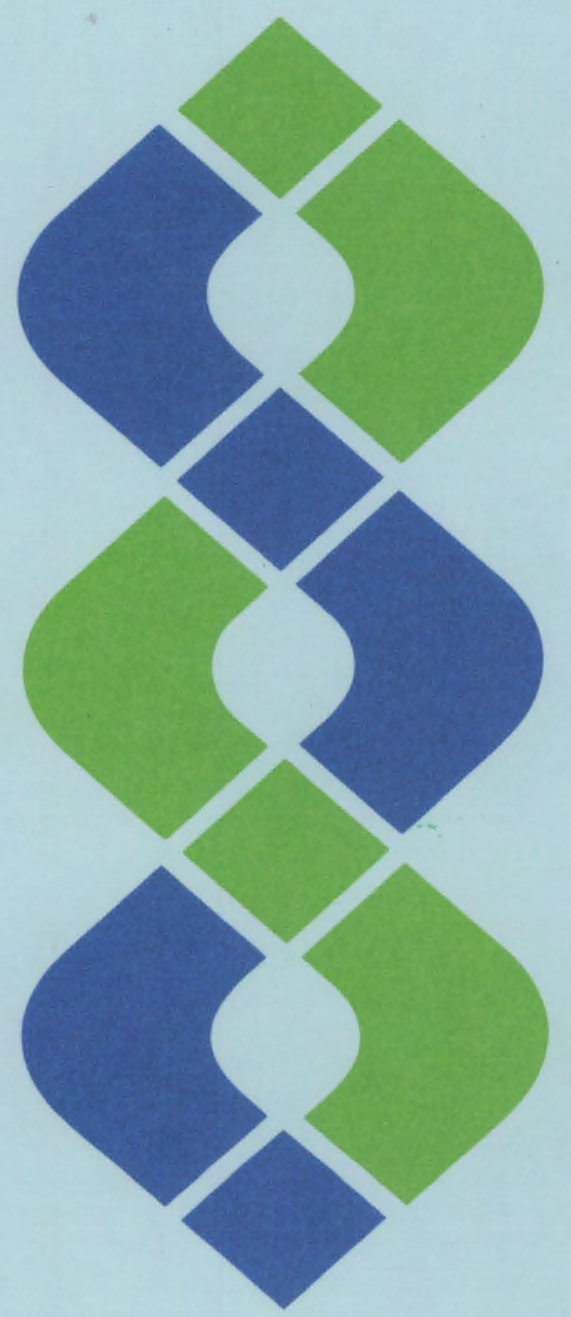

Prepared for the U.S. Department of Energy under Contract DE-AC06-76RLO 1830

Pacific Northwest Laboratory Operated for the U.S. Department of Energy by Battelle Memorial Institute

\title{
Battelle
}




\title{
DISCLAIMER
}

This report was prepared as an account of work sponsored by an agency of the United States Government. Neither the United States Government nor any agency thereof, nor any of their employees, makes any warranty, express or implied, or assumes any legal liability or responsibility for the accuracy, completeness, or usefulness of any information, apparatus, product, or process disclosed, or represents that its use would not infringe privately owned rights. Reference herein to any specific commercial product, process, or service by trade name, trademark, manufacturer, or otherwise, does not necessarily constitute or imply its endorsement, recommendation, or favoring by the United States Government or any agency thereof. The views and opinions of authors expressed herein do not necessarily state or reflect those of the United States Government or any agency thereof.

\author{
PACIFIC NORTHWEST LABORATORY \\ operated by \\ BATTELLE \\ for the \\ UNITED STATES DEPARTMENT OF ENERGY \\ under Contract DE-AC06-76RLO 1830
}

\begin{tabular}{|c|c|}
\hline \multicolumn{2}{|c|}{ Printed in the United States of America } \\
\hline \multirow{2}{*}{\multicolumn{2}{|c|}{$\begin{array}{c}\text { Available from } \\
\text { National Technical Information Service }\end{array}$}} \\
\hline & \\
\hline \multirow{3}{*}{\multicolumn{2}{|c|}{$\begin{array}{c}\text { United States Department of Commerce } \\
5285 \text { Port Royal Road } \\
\text { Springfield, Virginia } 22161\end{array}$}} \\
\hline & \\
\hline & \\
\hline \multirow{2}{*}{\multicolumn{2}{|c|}{$\begin{array}{l}\text { NTIS Price Codes } \\
\text { Microfiche } \text { A } 01^{2}\end{array}$}} \\
\hline & \\
\hline \multicolumn{2}{|c|}{ Printed Copy } \\
\hline & Price \\
\hline Pages & Codes \\
\hline $001-025$ & $\mathrm{~A} 02$ \\
\hline $026-050$ & $\mathrm{~A} 03$ \\
\hline 051-075 & $\mathrm{AO4}$ \\
\hline $076-100$ & A05 \\
\hline $101-125$ & $\mathrm{~A} 06$ \\
\hline $126-150$ & A07 \\
\hline $151-175$ & $\mathrm{~A} 0 \mathrm{~B}$ \\
\hline $176-200$ & $\mathrm{~A} 09$ \\
\hline $201-225$ & A010 \\
\hline $226-250$ & A011 \\
\hline $251-275$ & $\mathrm{~A} 012$ \\
\hline $276-300$ & $\mathrm{~A} 013$ \\
\hline
\end{tabular}


PNL-5000 PT5

UC-41, 11

\section{Pacific Northwest Laboratory \\ Annual Report for 1983 to the DOE Office of the Assistant Secretary \\ for Environmental Protection, Safety and \\ Emergency Preparedness}

\section{Part 5 Overview and Assessment}

W. J. Bair and Staff Members

of Pacific Northwest Laboratory

February 1984

Prepared for

the U.S. Department of Energy

under Contract DE-AC06-76RLO 1830

Pacific Northwest Laboratory

Richland, Washington 99352 


\section{PREFACE}

This 1983 annual report from Pacific Northwest Laboratory (PNL) to the Department of Energy (DOE) describes research in environment, health, and safety conducted during fiscal year 1983. The report again consists of five parts, each in a separate volume.

The five parts of the report are oriented to particular segments of our program. Parts 1 to 4 report on research performed for the DOE Office of Health and Environmental Research in the Office of Energy Research. Part 5 reports progress on all research performed for the Assistant Secretary for Environmental Protection, Safety and Emergency Preparedness. In some instances, the volumes report on research funded by other DOE components or by other governmental entities under interagency agreements. Each part consists of project reports authored by scientists from several PNL research departments, reflecting the multidisciplinary nature of the research effort.

The parts of the 1983 Annual Report are:

Part 1: Biomedical Sciences

$$
\begin{array}{ll}
\text { Program Manager - J. F. Park } & \begin{array}{l}
\text { D. L. Felton, Report Coordinator and } \\
\text { Editor }
\end{array}
\end{array}
$$

Part 2: Ecological Sciences

$$
\begin{array}{ll}
\text { Program Manager - B. E. Vaughan } & \text { B. E. Vaughan, Report Coordinator } \\
& \text { C. M. Novich, Editor }
\end{array}
$$

Part 3: Atmospheric Sciences

Program Manager - C. E. Elderkin N. S. Laulainen, Report Coordinator 1. L. Downs-Berg, Editor

Part 4: Physical Sciences

Program Manager - J. M. Nielsen R. M. Garcia, Report Coordinator J. E. Danko, Editor

Part 5: Overview and Assessment

Program Managers - S. Marks W. A. Glass

R. W. Baalman, Report Coordinator and Editor

Activities of the scientists whose work is described in this annual report are broader in scope than the articles indicate. PNL staff have responded to numerous requests from DOE during the year for planning, for service on various task groups, and for special assistance.

Credit for this annual report goes to many scientists who performed the research and wrote the individual project reports, to the program managers who directed the research and coordinated the technical progress reports, to the editors who edited the 
individual project reports and assembled the five parts, and to Ray Baalman editor in chief, who directed the total effort.

W. J. Bair, Manager

S. Marks, Associate Manager

Environment, Health and Safety Research

Program

Previous reports in this series:

\section{Annual Report for}

$\begin{array}{ll}1951 & \text { W-25021, HW-25709 } \\ 1952 & \text { HW-27814, HW-28636 } \\ 1953 & \text { HW-30437, HW-30464 } \\ 1954 & \text { HW-30306, HW-33128, HW-35905, HW-35917 } \\ 1955 & \text { HW-39558, HW-41315, HW-41500 } \\ 1956 & \text { HW-47500 } \\ 1957 & \text { HW-53500 } \\ 1958 & \text { HW-59500 } \\ 1959 & \text { HW-63824, HW-65500 } \\ 1960 & \text { HW-69500, HW-70050 } \\ 1961 & \text { HW-72500, HW-73337 } \\ 1962 & \text { HW-76000, HW-77609 } \\ 1963 & \text { HW-80500, HW-81746 } \\ 1964 & \text { BNWL-122 } \\ 1965 & \text { BNWL-280; BNWL-235, Vol. 1-4; BNWL-361 } \\ 1966 & \text { BNWL-480, Vol. 1; BNWL-481, Vol. 2, Pt. 1-4 } \\ 1967 & \text { BNWL-714, Vol. 1; BNWL-715, Vol. 2, Pt. 1-4 } \\ 1968 & \text { BNWL-1050, Vol. 1, Pt. 1-2; BNWL-1051, Vol. 2, Pt. 1-3 } \\ 1969 & \text { BNWL-1306, Vol. 1, Pt. 1-2; BNWL-1307, Vol. 2, Pt. 1-3 } \\ 1970 & \text { BNWL-1550, Vol. 1, Pt. 1-2; BNWL-1551, Vol. 2, Pt. 1-2 } \\ 1971 & \text { BNWL-1650, Vol. 1, Pt. 1-2; BNWL-1651, Vol. 2, Pt. 1-2 } \\ 1972 & \text { BNWL-1750, Vol. 1, Pt. 1-2; BNWL-1751, Vol. 2, Pt. 1-2 } \\ 1973 & \text { BNWL-1850, Pt. 1-4 } \\ 1974 & \text { BNWL-1950, Pt. 1-4 } \\ 1975 & \text { BNWL-2000, Pt. 1-4 } \\ 1976 & \text { BNWL-2100, Pt. 1-5 } \\ 1977 & \text { PNL-2500, Pt. 1-5 } \\ 1978 & \text { PNL-2850, Pt. 1-5 } \\ 1979 & \text { PNL-3300, Pt. 1-5 } \\ 1980 & \text { PNL-3700, Pt. 1-5 } \\ 1981 & \text { PNL-4100, Pt. 1-5 } \\ 1982 & \text { PNL-4600, Pt. 1-5 } \\ & \end{array}$




\section{FOREWORD}

Part 5 of the 1983 Annual Report to the Department of Energy's Assistant Secretary for Environmental Protection, Safety and Emergency Preparedness presents Pacific Northwest Laboratory's progress on work performed for the Office of Nuclear Safety and the Office of Operational Safety. For each project, as identified by the Field Task Proposal/Agreement, articles describe progress made during FY 1983. Authors of these articles represent a broad spectrum of capabilities derived from various segments of the Laboratory, reflecting the interdisciplinary nature of the work.

For additional information on any of the projects reported in Part 5, contact the authors of the articles. 


\section{CONTENTS}

PREFACE $\ldots \ldots \ldots \ldots \ldots \ldots \ldots \ldots \ldots \ldots \ldots \ldots \ldots \ldots \ldots \ldots \ldots \ldots \ldots \ldots \ldots \ldots \ldots \ldots$

FOREWORD $\ldots \ldots \ldots \ldots \ldots \ldots \ldots \ldots \ldots \ldots \ldots \ldots \ldots \ldots \ldots \ldots \ldots \ldots \ldots \ldots \ldots \ldots$ NUCLEAR SAFETY

Health Physics Support and Assistance to the Department of Energy

Technical Evaluation of the Capability of Present Instrumentation to Meet

the Draft ANSI Standard on Performance Specifications for Radiation Protection

Survey Instrumentation, J. L. Kenoyer, K. L. Swinth, R. L. Kathren ................. 1

Technical Evaluation of Draft ANSI Standard N13.30 "Performance

Criteria for Radiobioassay," D. R. Fisher, A. V. Robinson, R. T. Hadley ............. 2

Evaluation and Upgrade of DOE Internal Dosimetry, B. L. Murphy, K. R. Heid,

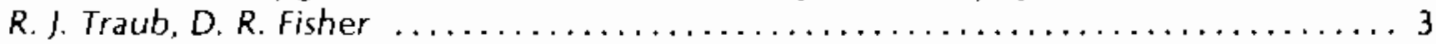

Workplace Air Sampling and Monitoring Upgrade, D. P. Higby, E. H. Carbaugh ...... 3

Characterization of Health Physics Technican Manpower Supply and Training

Programs, R. L. Kathren, ). C. Gillings, B. L. Murphy, .................... 4

Health Physics Training Program for DOE Headquarters Personnel, J. C. Cillings ....... 4

Occupational Radiation Exposure Records System Evaluation and Upgrade,

B. L. Murphy, D. W. Murphy, J. M. Selby ........................... 4

Analysis of QA Requirements, P. L. Roberson, C. D. Hooker, J. M. Selby ............ 4

Technical Evaluation of National and International Occupational Exposure

Recommendations, Standards, and Regulations, J. P. Corley, K. R. Heid,

B. L. Murphy, I. M. Selby ...................................... 5

ALARA Study, L. H. Munson, W. N. Herrington, D. P. Higby, R. L. Kathren ........... 5

Characterization of DOE Facility Emergency Preparedness, K. L. Swinth,

1. C. Gillings, I. M. Pisarick, A. V. Robinson, B. L. Murphy, I. M. Selby ............. 5

Neutron Depth Dose Study, R. I. Scherpelz ............................ 6

Neutron Instrument Development, L. W. Brackenbush, ). C. McDonald ............. 7

Technical Guidelines for Personnel Dosimetry Calibrations

Technical Guidelines for Personnel Calibrations, f. C. McDonald, R. A. Fox,

C. D. Hooker, J. L. Pappin, P. L. Roberson, K. L. Swinth ......................... 9

Guidelines for Dosimeter Calibrations, $P$. L. Roberson $\ldots \ldots \ldots \ldots \ldots \ldots \ldots \ldots \ldots$

Guidelines for Instrument Calibrations, K. L. Swinth ...................... 10

Intercomparison of Calibration Standards, f. C. McDonald .................... 10

Personnel Neutron Dosimeter Evaluation and Upgrade Progam

Personnel Neutron Dosimeter Evaluation and Upgrade Program, L.G. Faust,

D. E. Hadlock, L. W. Brackenbush, M. A. Parkhurst, J. C. McDonald, D. L. Haggard,

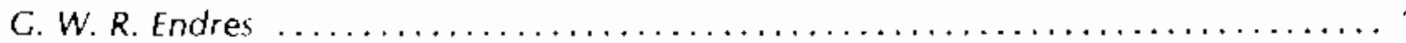

Beta Measurement Evaluation and Upgrade

Beta Measurement Evaluation and Upgrade K. L. Swinth, L. A. Rathbun,

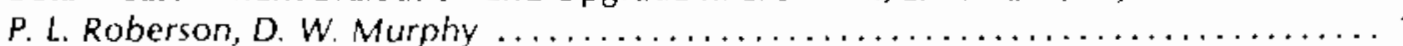

OPERATIONAL SAFETY

Policy Studies-Radiation

Policy Analysis-Northern Marshall Islands, W. J. Bair 


\section{Former Nuclear Site Risk Estimation}

Former Nuclear Site Risk Estimation, S. Marks, F. T. Cross, D. H. Denham.

W. E. Kennedy, Jr. .......................................... 21

Liquified Gaseous Fuels (LGF) Safety Studies

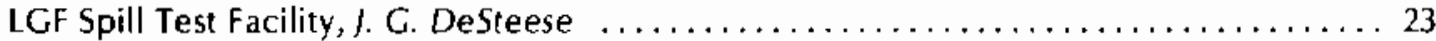

Environmental Protection, Support and Assistance

Environmental Protection Support and Assistance to DOE/OOS, J. P. Corley,

C. D. Corbit, P. A. Eddy, C. J. English, K. A. Hawley, R. E. Jaquish, I. C. Nelson,

L. S. Prater, J. K. Soldat, J. R. Raymond, D. G. Watson, E. C. Watson .............. 25

Effluent and Environmental Monitoring Guides, J. P. Corley .................. 25

Quality Assurance Review and Recommendations, R. E. Jaquish $\ldots \ldots \ldots \ldots \ldots \ldots \ldots$

Environmental Dose Modeling Review, J. P. Corley . . . . . . . . . . . . . . . . . 25

Summary of Environmental Reports, K. A. Hawley ....................... 25

Reporting Systems for Environmental Information, R. E. Jaquish $\ldots \ldots \ldots \ldots \ldots \ldots \ldots 26$

Follow-up to Environmental Impact Statement Commitments, I. C. Nelson ........... 26

Ground-Water Monitoring, P. A. Eddy, J. R. Raymond .................... 26

DOE Environmental Protection Information Meeting, J. P. Corley ............... 26

Special Assistance, R. E. Jaquish ................................... 26

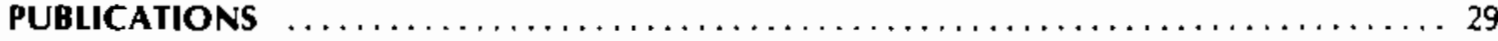

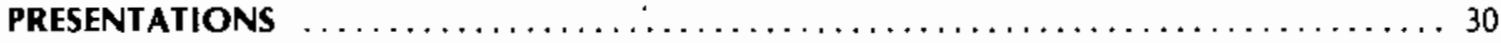

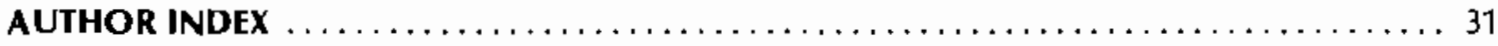

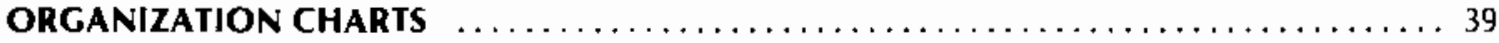

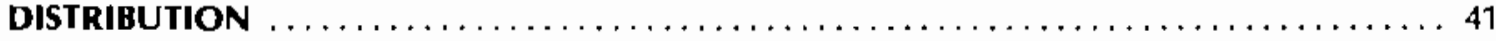


Nuclear

Safety 


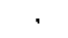




\section{NUCLEAR SAFETY}

- Health Physics Support and Assistance to the Department of Energy

- Technical Guidelines for Personnel Dosimetry Calibrations

- Personnel Neutron Dosimeter Evaluation and Upgrade Program

- Beta Measurement Evaluation and Upgrade

To establish and maintain an effective nuclear safety program, DOE has assigned to the Office of Nuclear Safety responsibility for developing and promulgating nuclear safety policy, standards and guidance and for DOE-wide independent overview, support, and counsel. The objective of the Nuclear Safety Program is to assure that the activities of the Department of Energy (DOE) and its contractors are in full compliance with DOE and other applicable nuclear safety, health and emergency preparedness standards and regulations and to provide technical support to DOE Office of Nuclear Safety.

The major emphasis at Pacific Northwest Laboratory continues to be on developing criteria, instruments, and methods to assure that radiation exposure to occupational personnel and to people in the environs of nuclear facilities is maintained as low as reasonably achievable. Particular emphasis has been placed on improving basic personnel exposure measurement and recording programs and on improving reporting systems.

-Bullets denote Field Task Proposal/Agreement (FTPA) titles. 



\section{- Health Physics Support and Assistance to the Department of Energy}

Pacific Northwest Laboratory functions as the lead laboratory providing health physics support and assistance to the Office of Nuclear Safety, Department of Energy (DOE), on special studies principally associated with the analysis of impact of standards, regulations, and engineering and administrative actions on occupational and environmental exposure. Support and assistance are also provided for other specific studies identified by DOE as priorities. The designation of lead laboratory in health physics, with an agreement and budget in place, provides the Division with the additional expertise necessary to respond to the many questions and situations that arise during the operation of their numerous nuclear energy research, development and demonstration facilities.

\section{G. Faust, J. M. Selby}

TECHNICAL EVALUATION OF THE CAPABILITY OF PRESENT INSTRUMENTATION TO MEET THE DRAFT ANSI STANDARD ON PERFORMMNCE SPECIFICATIONS FOR RADIATION PROTECTION SURVEY INSTRUMENTATION

\section{J. L. Kenoyer, K. L. Swinth, R. L. Kathren}

The objectives of this project are to evaluate the applicability and practicability of the proposed ANSI standard (ANSI N42.17), "Performance Specifications for Health Physics Instrumentation," to determine the degree of conformance to the proposed standard of selected currently available comercial instruments; to develop a formal test and evaluation protocol and specific procedures; and to lay the groundwork for establishing a permanent testing and certification laboratory.

During the past year, approximately 75 health physics instruments were procured for test and evaluation. Three methods of procurement have been used to date: (1) direct purchase of instruments from the manufacturer, (2) the loan of instruments by manufacturers, and (3) the loan of instruments by DOE laboratories. The types of instruments have been grouped into six categories: ionization chambers, GM detectors, alpha detectors, neutron monitors, air monitors, and others not covered by the preceding categories.

Instrument test and evaluation procedures were developed that followed existing, proposed, and draft standards and guides. All of the requirements stated in ANSI N42.17 are covered by these procedures. Procedures were written for the following tests: inspection, AC power, battery lifetime, alarm reset, stability, geotropism, response time, accuracy, precision, IER energy dependence, beta energy dependence, neutron enerqy dependence, radiation overloads, angular dependence, extracameral response, nonionizing electromagnetic radiation, electrostatic fields, magnetic fields, interfering ionizing radiations, tem-

*This task is jointly sponsored by the Nuclear Regulatory Comission. perature, humidity, ambient pressure, vibration, and shock.

Development of test and evaluation procedures to be used under extreme conditions was initiated during this fiscal year. Extremerange testing procedures will include temperature (extremes and shock testing), humidity, ambient pressure, vibration, shock, and exposure rate.

New testing facilities that have been installed and characterized include an environmental chamber for controlled temperature and humidity tests, a pressure/vacuum exposure chamber, vibration tables, shock-testing equipment, and a radio-frequency field generation system. With the exception of a few highly specialized tests, PNL has the facilities for all the required testing. Arrangements have been investigated for specialized testing at other laboratories where required by the standard.

The testing phase of the program was initiated, and during the fiscal year more than 320 tests were performed on a thorough cross section of the instruments that have been procured. Tests are assumed to apply to all instruments of a particular class and will thus permit evaluation of the perfomance specifications in the draft ANSI standard. Initial testing results have identified some weaknesses in the draft standard; they have also identified unsatisfactory performance of instruments during specific tests. Selected results from the testing program are 1 isted in Table 1; results from nine different tests using ion chambers and GM detectors are represented.

For the instruments tested to date, the GM detectors and ion chamber instruments fall into two distinct categories. Ion chamber instruments generally lack the sensitivity of the GM detectors but can meet the requirements of the standard. The GM detectors seldom meet the test of radiation response and electronic requirements of the standard, and their poor precision makes it difficult to make definitive statements concerning their performance on some tests. 
TABLE 1. Selected Results from the Testing Program

\begin{tabular}{|c|c|c|c|c|}
\hline \multirow[b]{2}{*}{ Test } & \multicolumn{2}{|c|}{$\begin{array}{c}\text { No. of } \\
\text { Instruments } \\
\text { Tested }\end{array}$} & \multicolumn{2}{|c|}{$\begin{array}{c}\text { No. of } \\
\text { Instruments } \\
\text { that Failed }\end{array}$} \\
\hline & Ion Chamber & $G M$ & Ion Chamber & $G M$ \\
\hline Stability & 10 & 30 & 0 & 9 \\
\hline Geotropism & 8 & 14 & 3 & 1 \\
\hline Response Time & 0 & 20 & 0 & 11 \\
\hline Accuracy & 4 & 12 & 1 & 6 \\
\hline $\begin{array}{l}\text { Energy } \\
\text { Dependence }\end{array}$ & 9 & 7 & 4 & 7 \\
\hline Temperature & 15 & 19 & 9 & 0 \\
\hline Humidity & 5 & 17 & 1 & 4 \\
\hline $\begin{array}{l}\text { Ambient } \\
\text { Pressure }\end{array}$ & 5 & 5 & 0 & 0 \\
\hline
\end{tabular}

Recommendations to the ANSI working group will inciude comments on: (1) derivation of statistically reliable data, (2) the precision requirement of the relative standard deviation of $\leq 2.5 \%$ on all ranges, (3) equilibration periods for the environmental tests, and (4) the need for quality assurance information in the standard.

TECHNICAL EVALUATION OF DRAFT ANSI STANDARD N13.30 "PERFORMANCE CRITERIA FOR RADIOBIOASSAY"*

D. R. Fisher, A. V. Robinson, R. T. Hadley

The purpose of this study is to evaluate the adequacy of draft ANSI Standard N13.30 by conducting a nationwide bioassay intercomparison test. The study involves the performance testing of in-vitro and in-vivo service laboratories against minimum criteria for accuracy and precision specified in the draft standard.

During the past year, the first of two rounds of intercomparison testing was conducted. Invitations were extended to four DOE whole-body counting laboratories, six utilities and one fuel fabrication facility to participate in the in-vivo testing. Similarly, forty invitro bioassay laboratories were invited to participate in the first round intercomparison. Of the latter, twenty-one laboratories accepted the invitation. All radioactive materials employed in the testing were provided by the Nationat Bureau of Standards.

A torso phantom with three pairs of interchangeable lungs tagged with $235 \mathrm{~J}, 241$ An and

This task is joint y sponsored by the Nuclear Regulatory Commission.
$60 \mathrm{Co}$, respectively, was employed. The Tungs were prepared using a foaming polyurethane polymer. A point source of enriched $40 \mathrm{~K}$ was imbedded into the heart cavity of the torso phantom to provide a natura $40 \mathrm{~K}$ background interference.

A whole-body bottle phantom was purchased and filled with a gelatinous matrix containing precisely known quantities of fission and activation products $\left(137 \mathrm{Cs}, 144 \mathrm{Ce}\right.$ and $\left.{ }^{60} \mathrm{Co}\right)$ along with background interference radionuclides $\left({ }^{\circ 0} \mathrm{Sr}\right.$ and $\left.40 \mathrm{~K}\right)$.

The two phantons were shipped to participating in-vivo counting facilities for measurements, one facility at a time. This phase is in progress, and results will not be presented at this time.

A total of 560 samples of artificial urine containing carefully controlled guantities of ${ }^{3} \mathrm{H},{ }^{238} \mathrm{Pu}, 241 \mathrm{Am},{ }^{90} \mathrm{Sr}, \mathrm{U}$ (nat) or ${ }^{137} \mathrm{Cs}$ were prepared and shipped to participating invitro laboratories. At the same time, a third-party cross-check laboratory verified that the intended activity levels were present in the test samples.

The measurement results from participating bioassay laboratories were received and analyzed according to the statistical methods of the draft Standard. Analytical criteria for passage or failure were defined by the following:

1. minimum detectable amount (MDA) $\leq$ the acceptabie MDA

2. relative bias within the range -0.25 to +0.50

3. accuracy parameter $<0.40$.

Failure was defined as the inability to pass any one of the above three analytical performance criteria.

The intercomparison results are shown in Tables 1 and 2. Bioassay laboratories had difficulties meeting the draft Standard perform. ance criteria in many categories. The causes of test failures varjed markedly. Failures to measure ${ }^{238} \mathrm{Pu}$ and $241 \mathrm{Am}$ were usually related to difficulties in precision, whereas failures to measure natural uranium most often involved difficulties meeting criteria for relative bias. Failures to adequately measure $137 \mathrm{Cs}$ were largely attributable to unacceptable MDAs.

The test results indicate a need for laboratory accreditation to ensure quality bioassay results. The testing program provides an opportunity for laboratories to assess their performance in light of industry standards and to identify areas of weakness; it also reinforces the need for continual quality assurance. 
TABLE 1. In-Vitro Measurements Failing One or More of the Three Draft ANSI Standard N13.30 Analytical Performance Criteria (Accuracy, Precision, or MDA)

\begin{tabular}{lccc} 
Test Category & $\begin{array}{c}\text { Percent Analytica! } \\
\text { Failures Among } \\
\text { Laboratories That } \\
\text { Reported Results }\end{array}$ & $\begin{array}{c}\text { Total } \\
\text { Failures, (a) } \\
\text { Percent }\end{array}$ \\
\cline { 1 - 2 } $\begin{array}{l}\text { Alphid Scintillation } \\
\text { Beta Measurements }\end{array}$ & 11 & 22 \\
$\begin{array}{l}\text { Fluorescence } \\
\text { Measurements }\end{array}$ & 50 & 72 \\
$\begin{array}{l}\text { Gamma } \\
\text { Spectrometry }\end{array}$ & 43 & 50 \\
& 43 & 56
\end{tabular}

(a) Inciudes participating laboratories that failed to report results.

TABLE 2. Summary of Failures by Performance Criterion

\begin{tabular}{lc} 
Measure of Performance & Percent Failure \\
\cline { 2 - 2 } Minimum Detectable Amount & 28 \\
Relative Bias & 12 \\
Accuracy & 4 \\
Not Reporing Results & 29 \\
Any of the Above & 55
\end{tabular}

EVALUATION AND UPGRADE OF DOE INTERNAL DOSIMETRY

B. L. Murphy, K. R. Heid, R. J. Traub, D. R. Fisher

The purpose of this task is to characterize current practices in internal dosimetry at DOE facilities and evaluate those practices with respect to consistency among DOE contractors. This task is multifaceted in that ali aspects of an internal dosimetry program are addressed. Items considered include, but are not necessarily limited to, record systems and ease of information retrieval; ease of integrating internal dose and external dose; modeling systems employed, including ability to modify mod. els depending on excretion data, and verification of computer codes utilized; bioassay procedures, including quality control; and ability to relate air concentration data to individual workers and bioassay data. This task will also identify collective and individual strengths and weaknesses in the assessment of internal dose by DOE contractors. Furthemore, it will serve as a basis by which these practices can be improved. Initial efforts in this task were directed toward development of a comprehensive. program plan.

A comprehensive questionnaire was prepared and has been sent to the field offices through DOE Headquarters. The topics addressed by this questionnaire include documentation, bioassay, procedures, data anolysis/interpretation, quality assurance, air monitoring/sampling program, and records. The questionnaire also contained a section in which several questions were posed to obtain objective comments on such topics as the current state of internal dosimetry practices and improvements that could be made.

The questionnaires were distributed in September 1983. They will be analyzed by the second quarter of FY 1984.

A survey of the available 1iterature concerning internal dosimetry has been initiated. Particular emphasis has been placed on material related to the practical application of ICRP-2.6, metabolic models and available computer codes for assessment of internal exposure. A portion of this work supported the Standards Evaluation Task. This task also supported auxiliary studies to complement the ongoing perfomance testing of radiobioassay laboratories for the technical evaluation of draft ANSI Standard N13.30. These studies are directed toward determining the validity of artificial urine for intercomparison testing.

WORKPLACE AIR SAMPLING AND MONITORING UPGRADE

D. P. Higby, E. H. Carbaugh

The purpose of this task is to evaluate the current status of workplace air sampling and monitoring at DOE and DOE contractor facilities and to identify specific areas for upgrading. Workplace air sampling and monitoring are comnonly used as indications of the effectiveness of engineered controls on dispersible radioactive materials. Less common$1 y$, air sampling and monitoring results are used to evaluate personnel exposure to airborne radionuclides. Although the accuracy and precision of existing air sampling and monitoring techniques are typically not adequate for this purpose, proposed regulatory changes may place increased emphas is on the use of air sampling to assess interma? dose.

The initial effort included the development of a comprehensive long-range program plan. The plan includes the establishment of an 
aerosol testing laboratory, development of performance criteria for air sampling and monitoring equipment, and development of an improved workplace aerosol monitoring instrument.

A detailed air sampling and monitoring questionnaire was sent to DOE contractors through the respective field offices in the fourth quarter of $F Y$ 1983. This questionnajre covered eight aspects of workplace air sampling and monitoring:

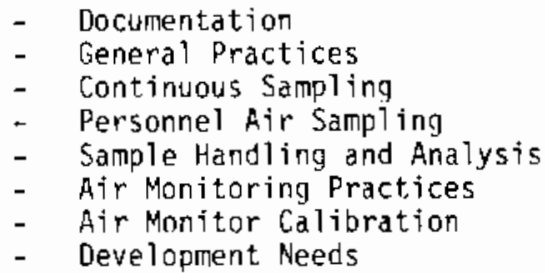

Final tabulation and analysis of responses to the questionnaire will be completed once all responses are received.

This task supported a subcontract to Lawrence Livermore National Laboratory to develop an improved transuranic aerosol monitor. Progress was made this year on improving the filter transport system, energy resolution and background interference.

CHARACTERIZATION OF HEALTH PHYSICS TECHNICIAN MANPOWER SUPPLY ANO TRAINING PROGRAMS

R. L. Kathren, J. C. Gillings, B. L. Murphy

This study has two purposes: (1) to determine the current status and recent trends in radiation safety manpower supply and demand among DOE contractors, and (2) to document the scope of radiation safety training activities within the DOE contractor system.

A questionnaire was developed in conjunction with Oak Ridge Associated Universities (ORAU) to gather data in these two areas. The questionnaire was sent to DOE field offices in the second quarter of FY 1983. Responses were received and tabulated in the third and fourth quarters of FY 1983 by ORAL.

In Fy 1984, conclusions and recomendations regarding manpower supply and demand and training practices will be developed.

HEALTH PHYSICS TRAINING PROGRAM FOR DOE HEADQUARTERS PERSONNEL

\section{J. C. Gillings}

A two-week health physics training course was presented at PNL to Dr. George Rotariu and Dr. Greg O'Alessio November 29 through Decem-

ber 17 . The course included a comprehensive review of health physics principles and practices and site visits and lectures by llanford area contractors. The following groups participated in this training:

PNL - External Dosimetry Records, Instrument Calibration and Evaluation Lab, Environmental Monitoring, Transportation, Internal Dosimetry

RHO - Transportation, Radiation Engineering, Radiation Monitoring

UNC - N Reactor, Radiological Engineering

OCCUPATIONAL RADIATION EXPOSURE RECORDS SYSTEM EVALUATION AND UPGRADE

B. L. Murphy, D. W. Murphy, J. M. Selby

The objective of this report is to evaluate and provide recommendations for improvement to the DOE-wide Occupational Radiation Exposure Record System. During FY 1982, alternatives upgrading the system were developed from the information that was reported in the previous two reports, "Overview of DOE Radiation Exposure Information Reporting System, REIRS," and "Current Personnel Dosimetry Practices at DOE Facilities." An ad hoc committee on Occupar tion Exposure Registry Upgrade consisting of twe lve members was assembled to provide guidance. Comments received from the field have been incorporated intn the report, which will be published in the first quarter of FY 1984. Work has been initiated on the development of performance criteria for the new record system.

\section{ANALYYSIS OF OA REQUIREMENTS}

P. L. Roberson, C. D. Hooker, J. M. Selby

The purpose of this study is to develop a program to evaluate the performance of DOE occupational exposure measurement systems. Initial1y the program will test dosimetry system performance. Development of a DOE standard for performance testing was begun; development of procedures to be used by the performance testing laboratory was initiated.

The DOE standard was based on the American National Standard, Criteria for Testing Personnel Dosimetry Perfomance, ANSI N13.11-1983 and the recommendations in Guidelines for the Calibration of Personnel Dosimeters PNL-4515 (Roberson and Holbrook 1983). The recommendations in PNL -4515 resulted from an analys is of ANSI N13.11 performed during the development of a data base on the performance of DOE dosimetry processors. Additional information is presented under "Technical Guidelines for Personnel Dosimetry Calibrations" in this document. 
The procedures manual will cover dosimeter handling, exposure sequencing, quality assurance, radiation field standardization, dosimeter irradiation uncertainty analys is, and liaison with the National Bureau of Standards.

TECHNICAL EVALUATION OF NATIONAL AND INTERNATIONAL OCCUPATIONAL EXPOSURE RECOMMENDATIONS, STANDARDS, AND REGULATIONS

J. P. Corley, K. R. Heid, B. L. Murphy, J. M. Selby

The obiective of this task is to provide a timely technical evaluation of national and international occupational exposure recommendations, standards, and regulations to determine in particular their technical accuracy, their impact on DOE operations, and compatibility with ODE operations and orders. As appropriate, technical expertise is drawn from other DOE contractor laboratories to assist in the evaluation. In Fy 1983, evaluations were performed of ICP.P Publication 26; proposed NRC revision to 10 CFR 20 and 10 CFR 140; proposed EPA revision to Federal Radiation Protection Guidance; Transuranium in the General Environment (EPA); Clean Air Act (EPA); and numerous ISO, IAEA, NEA, and ANSI standards. A Technical Advisory Committee consisting of representatives from several DOE contractor laboratories was fomed to assist with evaluations that specifically affected occupational exposure regulations.

\section{ALARA STUDY}

L. H. Munson, R. L. Kathren, W. N. Herrington, D. P. Higby

In early 1980, a manual "Guide to Reducing Radiation Exposure to As Low As Reasonably Achievable (ALARA)," was published as DOE/Ev 1830-T5. This document has since been specified as mandatory in the DOE Orders. Since its publication, existing standards have been revised and upgraded, and increasingly detailed interpretations of ICRP and NCRP recomtiendations have been promulgated. Thus, revision and upgrading of the guide are necessary to maintain DOE leadership in the application of ALARA in radiation protection.

This task was initiated in Fy 1983, with the objective to review and upgrade DOE guidance on ALARA. The existing general guide is being revised to reflect changes in ALARA practices and concepts and to include the development of additional detailed guidance as necessary. A draft of the revised guide has been sent to the sponsor for comment prior to circulaticn for more genera? peer review.

Additional ALARA manuals providing in-depth guidance will be developed. These may be developed for specific types of facilities (e.g., reactors, fuel fabrication plants, accelerators, radiological laboratories, fuel processing facilities, waste repositories and enrichment facilities) or for specific topical areas (e.g., facility design, training, instrumentation).

\section{CHARACTERIZATION OF DOE FACILITY EMERGENCY PREPAREDNESS}

K. L. Swinth, J. C. Gillings, J. M. Pisarick, A. V. Robinson, B. L. Murphy, J. M. Selby

The purpose of the energency preparedness task is to update and expand the emergency instru. ment performance criteria published in the $1970 \mathrm{~s}$ and to provide guidance on the proper elements of emergency instrument programs. The work will entail development of a generic document on emergency preparedness instrumentation fallowed by documents on emercency instrument performance criteria and requirements for specific categories of facilities.

In 1980, following the Three Mile Island incident, DOE requested $\mathrm{PNL}$ to expand and update an earlier study on emergency instrumentation preparedness conducted in 1970. The 1970 survey study resulted in four reports on performance criteria for radiological emergency instrumentation. Three of these documents addressed criteria for emergency instrumentation at (1) reactors, (2) mixed oxide fuel fabrication plants, and (3) fuel reprocessing plants. The fourth document addressed evaluation testing and calibration methodology for these instruments.

These early studies examined source terms and potential accident scenarios to determine the required performance characteristics of instrumentation used to assess such releases. The instrumentation included meteorological instruments, radiological instruments for measurement of airborne and liquid releases, criticality monitors, survey instrumentation, and stack monitors.

The update of this earlier study has inciuded a survey of $30 \mathrm{DOE}$ contractors to assess current emergency preparedness capabilities.

This survey showed that in approximately onehalf of the criteria surveyed in both 1970 and 1980 there was no significant improvement. Approximately $30 \%$ of the criterid that were included in both surveys showed an improvement, and $20 \%$ indicated a decline in emergency response capabilities.

There has been little change in the area of medical treatrent arrangements, gaseous effluent monitoring at the point of release, boundary and environs air monitoring, and meteorological measurements, with the 
following exceptions: (1) the performance of sampling and analysis of gaseous effluents showed a marked increase between 1970 and 1980 with a corresponding increase in the sampling of gases as compared to particles, and (2) there was a marked decrease in the reported abilities of the contractors to perform ground deposition and dispersion calculations for airborne effluents.

Liquid effluent monitoring showed an overall improvement between 1970 and 1980; more sites seemed to provide continuous monitoring of 11 quid effluents, and the system was reported to function during a design basis accident. There was a greater emphasis on intermittent monitoring of environmental dose rates in 1980 , but a lesser percentage of respondents reported that health physics approval was required for system deactivation. Finally, although emergency communications systems remained essentially the same (except for an increased use of the pageboy call system), provisions for emergency comsunication channels to the local police, local governient, and the public news media showed a decline from 1970 to 1980 .

The review has also shown that the earlier instrument performance criteria should be updated to reflect the current state-of-the-art. Refinements have been made in models for atmospheric transport, and new and improved instruments have become available including the current trend toward digital instruments. Several standards have been written or are in preparation covering instrument performance under a variety of conditions. Recommendations on emergency preparedness instrumentation will be updated to reflect changes in DOE facility types, instrument performance criter$i a$ as reflected in standards, and state-of-theart instrumentation.

Updating of the reports has started with a document on generic requirements for emergency instrument preparedness at DoE facilities. This report covers the elements common to all emergency preparedness programs regardless of facility type. Following completion of this report, specific documents will be prepared for all facility types in the DOE family. This will include reports examining the specific requirements for fuel fabrication, reactors, reprocessing, research, enrichment, and weapons facilities.

\section{NEUTRON DEPTH DOSE STUDY}

\section{R. I. Scherpelz}

The determination of personnel doses due to exposure to a field of neutron radiation usually depends on the use of a set of flux-todose conversion factors. These factors are applied to an energy-dependent flux distribution at the body surface to derive the dose and dose equivalent values resulting from the neutron exposure. Some of the commonly used tabulations of these flux-to-dose conversion factors are based on calculations performed at widely spaced energy points, and different interpolating schemes can lead to widely varying conversion values for energy points not explicitly included in the tabulation. Tabulations are often based on calculations with little experimental verification of the modeling technique. This study is adding improvements to the tabulations of neutron flux-to-dose conversion factors by calculating neutron $f l u x$, dose and dose equivalent distributions in a tissue-equivalent phantom exposed to a beam of monoenergetic neutrons. These depth dose profiles will be used to derive flux-to-dose conversion factors. Some of these factors will be determined for comparison with previousiy published values, and some will be intended to fill in gaps. The model used in the calculation is also being designed to aliow for a comparison with planned experimentat measurements.

The computer code BMC-MG (Battelle Monte Carlo-Multigroup) is the code used to perform the depth dose calculations. It is a sophisticated neutron transport code using the Monte Carlo methodology, well-suited to these calculations. Two different cross-section sets are being used to develop the model: a 27 neutron-group set derived from ENDF/B-III data, and a newer coupled neutron-gamma set derived from ENDF/B-IV data. The calculational model has been developed to implement the advanced features of $B M C-M G$ for efficient, cost-effective operation. Some of these features include Russian roulette, particle splitting, importance weighting by region, and thermal weighting. The model used for the calculations has thus been optimized and is being used for calculating depth dose profiles.

A typical example of a depth dose calculation is presented in the accompanying figure. This graph plots dose as a function of depth into the phantom for a parallel beam of neutrons having an energy of $1 \mathrm{MeV}$, and a total fluence of $1.0 \mathrm{n} / \mathrm{cm}^{2}$. The dose points for this calculation were arranged in a line parallel to the

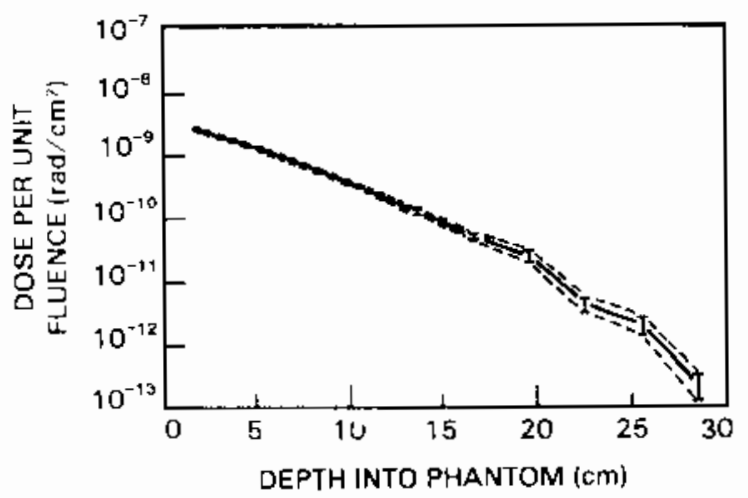

FIGURE 1. Dose vs Depth into Phantom - 1 MeV 
neutron beam, passing through the center of the cylindrical phantom. These calculations were made with the 27-neutron group crosssection set, and the results compare well with previously published values.

\section{NEUTRON INSTRUMENT DEVELOPMENT}

\section{W. Brackenbush, J. C. McDonald}

There are two objectives to this task: (1) to investigate the use of tissue equivalent proportional counters (TEPC) as standard neutron instruments to help characterize neutron fields and (2) to investigate new types of neutron detectors that could potentially be useful dosimeters. There is renewed interest in tissue equivalent proportional counters with the release of the "NCRP Statement on Dose Limits for Neutrons," in which the National Council on Radiation Protection and Measurements discusses possible changes in the recommended absorbed dose limits for neutrons. References cited in the NCRP statement propose the redefinition of quality factor in terms of lineal energy, which is a quantity directly measured by the TEPC, rather than in terms of 1 inear energy transfer (LET), which is presentiy used. Tissue equivalent proportional counters can also be used to directly measure absorbed dose and are absolute dosimeters, since they are selfucalibrating. A program has been established for several years to develop the TEPC into a more practical health physics instrument to directly measure $a b$ sorbed dose from any type of ionizing radiation. The Pacific Northwest Laboratory and several other laboratories have demonstrated that it is possible to simultaneously measure neutron and gama dose with a single proportional counter and two amplifiers operated at different gains. This is possible using a propane-based tissue equivalent filling gas, which has a higher gain than the methane-based gas previously used.

Previous work utilized spherical counters, which are expensive and difficult to build. Current work emphasizes cylindrical tissue equivalent proportional counters, which may be manufactured commercialiy. Algorithms for determining LET distributions and quality factors have already been established for spherical counters. Efforts this year were directed at establishing similar algorithms for cylindrical proportional counters. These results and limitations in the various methods for determining quality factors were reported at the Tenth International Neutron Dosimetry Workshop sponsored by DOE and were published in PNL-SA11686.

Neutron dosimeters in use today have improved on well established techniques. No really new, innovative practical neutron dosimeter has been developed in the past 20 years. A1i neutron dosimeters in use today are limited because of an energy dependence problem (i.e., the responses per unit of dose equivalent are not constant, but vary with neutron energy). Since the major contribution to neutron dose in tissue is neutron interactions with hydrogen, it appears that a dosimeter containing hydrogen or matching the cross section of hydrogen with energy could overcome some of the energy dependence problems with existing dosimeters. A limited amount of work with organic semiconductors and amorphous silicon (which contains 10 to 50 atom percent hydrogen) is presented in PNL-SA-11461. However, these devices have not proved sensitive enough for a practical dosimeter, and more work needs to be performed. 



\section{- Technicial Guidelines for Personnel Dosimetry Calibrations}

This program continues to provide technical evaluations of personnel dosimetry calibration procedures at DOE laboratories. This information and guidance will help to optimize equipment and procedures for radiological calibrations. The current tasks include developing a performance data base for radiation protection instruments and preparing guidelines for their calibration. In addition, an intercomparison program for laboratory calibrations was initiated.

\section{TECHNICAL GUIDELINES FOR PERSONNEL DOSIMETRY} CALIBRATIONS

J. C. McDonald, R. A. Fox, C. D. Hooker, J. L. Pappin, P. L. Roberson, K. L. Swinth

The objectives of this program are to establish guidelines for the calibration of personnel dosimeters and radiation protection instruments. This quidance will help DOE laboratories institute optimum equipment and procedures for radiological calibrations in a costeffective and prompt manner. It will also establish a more uniform approach to dosimetry by reducing site-dependent differences in reported personnel doses that may arise from basic calibration differences.

This task was initiated by developing a performance data base on personnel dosimeters in use at DOE laboratories. The data were used to prepare guidelines for calibration of persomel dosimeters. The development of guidelines for the calibration of radiation protection instruments is being implemented by means of a survey of practices for DoE laboratories and an evaluation of current instrument standards.

An intercomparison program for laboratory calibrations was also initiated between major DOE calibration facilities. This program will help resolve any possible discrepancies and establish a firm basis for calibration standardization. It will also help during the implementation of calibration guidelines for both dosimeters and instruments.

\section{GUIDELINES FOR DOSIMETER CALIBRATIONS}

\section{P. L. Roberson}

A document, Guidelines for the Cal tbration of Personnel Dosimeters (Roberson et al. 1983a), was prepared. This guide describes minimum levels of acceptable performance for personnel dosimetry systems used at DOE facilities. The goal is to enhance the quality of radiological calibrations and the comparability of reported occupational doses between DOE facilities.

The guide defines a set of reference calibration techriques to encourage uniform dosimeter response. Also included are a standard by which personnel dosimetry systems can be evaluated and recommended design parameters for personnel dosimeters. Approximate limits for the energies of the radiation for which these guidelines are appropriate are 20 $\mathrm{keV}$ to $2 \mathrm{MeV}$ for photons; $0.5 \mathrm{MeV}$ to $4 \mathrm{MeV}$ for beta particles; and $100 \mathrm{keV}$ to $2 \mathrm{MeV}$ for neutrons. The procedures specified by the guidelines differ from those of ANSI N13.11-1983 in that they are designed to standardize and evaluate rather than test a personnel dosimetry system. The geometries of the calibration techniques follow those given in ANSI N13.1l as closely as practical.

The analysis of ANSI N13.11 as a standard for DOE was based on performance evaluations of selected personnel dosimetry systems in use at DOE facilities. The results of the analysis are as follows:

- The number of test categories was incomplete. Required additions include a low-energy beta source, a second neutron source, and an $x$-ray/neutron mixture category.

- The performance algorithm was arbitrarily specified. It was modified to meet recommendations of the International Commission on Radiation Units and Measurements (Report 20) and the National Council on Radiation Protection and Measurements (Report No. 57).

- The beta-particle specifications were insufficient. Specification of the acceptable range of depth dose was required to improve standardization of calibrations.

- The exposure-to-dose conversion factors for photons ( $C$ factors) did not match the calibration geometry; therefore, appropriate $C_{x}$ factors were used.

Recommendations for the design and use of personnel dosimetry systems are included; they were based on performance evaluations of selected DOE systems. 
In addition, the dosimeter performance characteristics described in our last annual report were reported in Performance Comparison: of Selected Personnel Dosimetry Systems in Use at the Department of Energy Facilities (Roberson et a). 1983b).

\section{GUIDELINES FOR INSTRUMENT CALIBRATIONS}

K. L. Swinth

A data tase is being developed to characterize the calibration techniques, the performance, and the types of instruments currently used at DOE facilities. A survey of DOE facilities and a compitation of data available from Hanford experience and data from related projects are both under way. Site visits to several major DOE laboratories and use of related data from the laboratories are planned. Experience from the calibration of instruments used in radiation protection at Hanford is being compiled and will form the basis of integration of data from other DOE sites. Experience gained from the ongoing evaluation of ANSI N42.1702 and additional evaluations deemed necessary will be used to determine instrument performance. Information has been tabulated on typical instrument performance, existing calibration capabilities, and calibration requirements (e.g., frequency of calibration, type of radiation, dose and energy ranges).

When new or more rigorous calibration requirements are established for instruments, tests will be performed to assure that they are practical. Uniform calibration requirements have not been established for many instruments. When they are established, the entire range of influencing parameters must be considered, such as energy response, temperature response, and envirommental influences.

\section{INTERCOMPARISON OF CALIBRATION STANDAROS}

\section{J. C. McDonald}

At the request of the DOE Office of Nuclear Safety, Health Physics Group an intercomparison study of radiological calibration standards is being conducted by Pacific Northwest Laboratory (PNL). The intent of the program is to identify and eliminate sources of variation in calibration procedures and techniques. This study, similar to one conducted in Europe, is expected to encourage greater communication between laboratories regarding field-tested procedures to be used to solve calibration problems specific to DoE facili. ties. Further, the program will provide DOE laboratories an opportunity to obtain independent checks of calibration standards.

The intercomparison program involves crosschecks of both instrument and dosimeter calibrations. Laboratories will have the opportunity to participate in four categories of testing: high energy photon, low energy photon, beta, and fast neutron. Laboratories participating in the study will be shipped a set of instruments and dosimeters and will be requested to expose the devices to their cal $i$ bration sources at specificd doses. The laboratories will report the instrument response and return the dosimeters to PNI for readout.

The intercomparison instruments are being routed from one laboratory to the next in a predetermined sequence. The instruments will be returned to PNL periodically for postintercomparison testing. The types of instruments used are listed below.

\section{Category}

\begin{tabular}{|c|c|}
\hline$x$ ray & $\begin{array}{l}\text { Capintec }{ }^{\star} M-30 \text { Ionization } \\
\text { Chamber } \\
\text { Wall Material: Shonka C-552 Air } \\
\text { Equivalent Plastic } \\
\text { Volume: } 28 \mathrm{cc} \text { (nominal) } \\
\text { Energy Range: } 15-1250 \mathrm{keV}\end{array}$ \\
\hline${ }^{137} \mathrm{Cs}$ & $\begin{array}{l}\text { Capintec PM-30 Ionization } \\
\text { Chamber with buildup cap }\end{array}$ \\
\hline Beta & $\begin{array}{l}\text { Far West Technology** EIC-1 } \\
\text { Extrapolation Chamber } \\
\text { Window Material: Conducting } \\
\text { Polyethylene } 6.9 \mathrm{mg} / \mathrm{cm}^{2} \text { thick } \\
\text { Electrode Separation: } 0.3 \text { to } \\
4.5 \mathrm{~mm}\end{array}$ \\
\hline Neutron & $\begin{array}{l}\text { Far West Technology IC- } 80 \\
\text { Ionization Chamber } \\
\text { Wall Material: Shonka A-150 } \\
\text { Tissue Equivalent Plastic } \\
\text { Volume: g0 cC (nominal) }\end{array}$ \\
\hline
\end{tabular}

\section{REFERENCES}

Roberson, P. L., et a]. 1983a. Guidelines for the Calibration of Personnel Dosineters. PNL-4515, Pacific Northest Laboratory, Richland, Washington.

Roberson, P. L., et al. 1983b. Performance Comparison of Selected Personnel Dosimetry Systems in Use at Department of Energy Facilities. PNL-3983, Pacific Northwest Laboratory, Richland, Washington.

\footnotetext{
Capintec Inc., Pittsburgh, PA

** Far West Technology Inc., Goleta, CA
} 


\section{- Personnel Neutron Dosimeter Evaluation and Upgrade Program}

A program was initiated during FY 1981 with Pacific Northwest Laboratory as the lead laboratory: (1) to evaluate response characteristics of personnel neutron dosimeter systems in current use at several DOE laboratories, and (2) to develop improved neutron detection techniques for use as personnel neutron dosimeters and/or portable instruments, and (3) to provide improved calibration procedures and techniques. Evaluation of neutron dosimeters from twelve DOE laboratories was completed during FY 1982.

\section{PERSONNEL NEUTRON DOSIMETER EVALUATION AND UPGRADE PROGRAM}

L. G. Faust, D. E. Hadlock, L. W. Brackenbush, M. A. Parkhurst, J. C. McDonald, D. L. Haggard, G. W. R. Endres

The objective of this program is to provide a continuing effort to resolve problems of assessing personnel neutron dose at DOE facilities. Progress during $F Y 1981$ and $F Y$ 1982 included: an assessment of the current status of personnel neutron dosimeter systems at DOE facilities; recomendations on methods of calibrating personnel neutron dosimeters; and continuing development of several concepts that show promise of upgrading the state-of-the-art in personnel neutron dosimetry. In addition, this program has continued to pursue improved personnel neutron dosimetry at DOE facilities and to provide DDE contractors with program accomplishments. This allows vendors the opportunity to manufacture developed prototypes in the form of commercially available dosimeters and/or instruments.

During FY 1983, PNL and other DOE laboratories as well as universities and private industry conducted research in nine principal areas: (1) technology transfer, (2) prototype evaluation, (3) field measurements, (4) dosimeter intercomparison, (5) track etch plastic (CR-39) technology, (6) dosimetry grade CR-39 (University of California), (7) combination dosimeter concepts (Lawrence Livemore National Laboratory), (8) remmeter dosimetry, and (9) semiconductor dosimetry. In addition, an Internationa?

Workshop was conducted. Many of the results of these studies were presented at the Tenth International Neutron Dosimetry Workshop held in Mexico August 30-September ?, 1983 and are included in the proceedings.

Transfer of program developments to field operations is being continued through the use of contractor meetings and workshops. Prototype dosimeters and instruments are being evaluated to detemine their potential for upgrading existing capability.

Field Measurements of neutron dose and spectra are being conducted in several DOE laboratories and commercial power reactors. This information, along with the measured responses of new devices, will allow determination of the accuracy of field neutron measurements and will be published at a later date.

Evaluation of neutron dosimeters from twelve DOE laboratories was conducted. The data and their analysis were published in an intercomparison report (McDonald 1983), which evaluates the dosimeters for accuracy, precision, lower dose detection, and energy response.

Field implementation of dosimetry grade CR-39 is being accomplished as its uniformity and long-term stability are established. Other selected concepts potentially capable of state-of-the-art improvements in personnel neutron dosimetry are also being developed.

\section{REFERENCE}

McDonald, J. C. et al. 1983. Response Characteristics of Selected Personnel Neutron Dosimeters. PNL-3982. Pacific Northwest Laboratory, Richland, Washington 



\section{- Beta Measurement Evaluation and Upgrade}

This program focuses on resolving the problems associated with the field measurement of the beta dose component at DOE facilities. Little attention has been paid to improving beta measurements during the past 10 or 15 years. The change in DOE programs, including increased efforts in improved waste management and D\&D facilities, coupled with beta measurement problems identified at TMI has heightened DOE's awareness for the need to improve beta measurements. In FY 1982, this program was begun to provide a continuing effort to identify problems associated with beta dose assessment at DOE facilities. Personnel beta dosimeters and instruments used at DOE facilities are being evaluated and characterized and includes (1) an assessment of measurement systems now in use, (2) development of improved calibration systems and procedures, (3) application of innovative beta dosimetry concepts, (4) investigation of new instruments or concepts for monitoring and spectroscopy, and (5) preparation of a "manual of good practice" to assure an adequate beta measurement program.

\section{BETA MEASUREMENT EVALUATION AND LIPGRADE}

K. L. Swinth, L. A. Rathbun, P. L. Roberson, D. W. Murphy

The Beta Measurement Evaluation and Upgrade program was initiated to review the problems associated with beta dosimetry practices. The work performed in FY 1983 can be classified into three major areas: (1) current practices, (2) dosimeter deveiopment, and (3) instrument development.

A questionnaire was developed and distributed to assess the current beta dosimetry practices at DOE laboratories. The responses to the questionnaire are expected during the first quarter of FY 1984. Based on the questionnaire, a report will be produced covering the current practices at DOE sites in relationship to beta dosimeters, beta instrumentation, and beta calibration methods. The report will summarize the weaknesses, strengths, and problem areas identified at various facilities.

Field measurements were initiated at a DOE facility where significant beta exposures exist. Beta spectral analyses were performed and beta dose rates determined using the multielement dosimeter being developed in conjunction with the program. The response of the instruments and dosimeters currently in use at the facility were conpared with the field measurement results. The data collected during the measurements are currently being analyzed.

Work continued on refining the multielement dosimeter for field applications. The num. ber of elements in the dosimeter was increased, calibrations were performed, and new algorithms were developed for analys is of the response. This has improved the information avaflable on beta fields.

Tests were performed at Pacific Northwest Laboratory on the graphite-backed thin TLD which is being developed by Kansas state University under subcontract to PNL. Tests showed that the thin TLD has an energy response that is relatively independent of beta energy. This type of chip has the potential for direct incorporation into present TLD badges.

A second dosimetry system is being developed under a subcontract to Internationa? Sensor Technology. This system uses an infrared laser system to heat the TLD chips and leads to selected area readout and an improved signal-to-noise ratio. Development of the prototype systen is complete, and the unit will be delivered to PNL for further test and evaluation during the first quarter of FY 1984.

Tests were performed on five commonly used ton chambers and one GM-type instrument to characterize their energy response. Over the beta end-point energy range of 0.225 to $3.5 \mathrm{MeV}$, the ratio of maximum to minimum response varied from a factor of 2.5 to a factor of 16 . This 117 ustrates the severe dependence of instrument response on beta energy. Additional tests are planned including tests of the effect of source geometry on instrument response. 

Operational Safety 



\section{OPERATIONAL SAFETY}

\section{- Policy Studies-Radiation}

\section{- Former Nuclear Site Risk Estimation}

\section{- LGF Safety Studies}

\section{- Environmental Protection, Support and Assistance}

The responsibility of the Department of Energy (DOE) Office of Operational Safety is to assure that DOE-controlled activities are conducted in a manner that will minimize risks to the public and employees and will provide protection for property and the environment. The program supports the various energy technologies by identifying and resolving safety problems; developing and issuing safety policies, standards, and criteria; assuring compliance with DOE, federal, and state safety regulations; and establishing procedures for reporting and investigating accidents in DOE operations.

The Office of Operational Safety also has responsibility for overview of the remedial action program conducted by the DOE Office of Nuclear Energy. Relevant past activities have included the development of methods for estimating health risk due to radiological contamination at former MED/AEC facilities and properties where uranium mill tailings were used as landfill. In addition to risk assessment, the overview role has now been expanded to include program technical support and assistance; quality assurance reviews and appraisals; radiological criteria and standards as well as radiological monitoring and surveys; and evaluations and recommendations. 



\section{- Policy Studies-Radiation}

The major effort on this project was to write a booklet for the Department of Energy to present to the people of the Marshall islands concerning radiological surveys of several northern atolls and islands in 1978.

POLICY ANALYSIS--NORTHERN MARSHALL ISLANOS

W.J. Bair

The purpose of this project was to write a booklet to support a Department of Energy (DOE) presentation to representatives of the government of the Marshall Islands and of several atolls in the northern Marshalls. The document, The Meaning of Radiation for Those Atolls in the Northern Part of the Marshall Islands That Were Surveyed in 1978, authored by W.J. Bair, J.W. Healy, and B.W. Wachholz (1982), describes the radiological conditions of several northern atolls and islands as of 1978 resulting from the nuclear weapons tests conducted in the Marshalls in the 1940 s and 1950s. The booklet summarizes Lawrence Livermore National Laboratory's dose assessments for people living on those isiands and atolls and discusses the possible health risks people might face if they live there now or in the future.

This dual-language booklet was drafted in English and translated into Marshallese using a dynamic-equivalent translation method. The English text is a modified literal translation of the Marshallese by A. Buck, M. Jelke, and $K$. Sam from the Marsha 11 Islands. M. C. Sheets created special graphics, and $R$. $W$. Baalman edited the booklet.

W.J. Bair participated with DOE representatives in a meeting with elected representatives of atolls in the northern Marshalls and officials of the government of the Republic of the Marshall Islands to explain the contents of the book and to answer questions.

\section{Reference}

Bair, W.J., J. W. Healy, and B.W. Wachholz. 1982. Melelen Radiation Ilo Ailin ko Ituion Ilo Majot, ko Rar Etali Ilo 1978: The Meaning of Radiation for Those Atolls in the Northern Part of the Marshall ls lands That Were Surveyed in 1978. DOE/NBM--1052. U.S. Department of Energy, Washington, D.C. 



\section{- Former Nuclear Site Risk Estimation}

This project has involved the estimation of health effects at formerly utilized MED/AEC nuclear sites or inactive uranium mill tailing sites. This activity is a component of the overview role of the Office of Operational Safety (OOS), specifically addressing the issue of risk assessment. During FY 1983, work progressed on development of the methodology used in health effects estimation, and reports of the results of health effects calculations were prepared for vicinity properties, principally in the Salt Lake City area.

\section{FORMER NUCLEAR SITE RISK ESTIMATION}

S. Marks, F. T. Cross, D. H. Denham, W. E. Kennedy, Jr.

To date, this project has been directed principally to the development of procedures to be followed in calculating estimates of projected health effects at formerly utilized MEO/AEC nuclear facilities or at properties in the vicinity of inactive uranium mill tailings sites. The principal activities have been primarily directed to vicinity properties in the Salt Lake City area. These are properties immediately adjacent to the deactivated Vitro uranium mill tailings pile or, more frequently, at a greater distance. In the latter case, tailings material had been transported to the properties at some past time for use as landfill. During FY 1983, reports were completed in final form for a number of properties and draft reports prepared on others.

Tasks under the project include characterization of the source term for each property, selection of an appropriate set of health risk coefficients, evaluation of risk from environmental pathways, calculation of estimated health effects, and suggestions for the revision of radiological survey procedures to improve the achievement of objectives under this project.

The radiological source term was described in a report for each property in which we summarized radiological survey data compiled by Oak Ridge National Laboratory (ORNL) and Mound Laboratory. The reports briefly identified the nature of activities conducted at each property, the physical characteristics of the site and structures upon it, and the presence of various types of land cover, either in or outside the structures, that may modify radiological exposure levels. Contour lines were mapped on diagrams of the properties to reflect the isopleths for gamma exposure rates when taken at 1 meter above ground. Building diagrams were incorporated in the property reports.

The source-term section described the bases for selection of gamana-ray and radon daughter exposure values that were used in the health effect calculations. The gamila-ray values were usually the arithmetic means of measurements in buildings or in areas of differing exposure within a building. Guidelines were developed for the selection of grab or continuous radon gas measurements or of grab radon daughter measurements for use in the health effect calculations. The basis for acceptance of a calculated equilibrium factor or use of a default factor of $30 \%$ was also discussed for each property.

In the vicinity properties considered to date, three types of exposure have entered into the calculation of projected health effects. These are gamma-ray exposure rates at 1.7 , radon daughter concentrations, and internal emitter exposure through the food pathway for two residential properties. The latter assumed the existence of home gardens on these properties that would provide a portion of the diet to the residents. In calculating health effects resulting from gamma exposure, the end point was cancer, and the currently accepted lifetime risk coefficient of $100 \times 10^{-6}$ cancer cases per rem of exposure was employed. In the case of radon daughter exposure, a risk coefficient developed by the Task Group for Radon and Daughters of NCRP Scientific Comprittee 57 was used. The risk coefficient is $5.6 \times 10^{-3} / \mathrm{WLM} / \mathrm{yr}$ for 1 ifetime risk and lifetime environmental exposure for populations having a mixture of ages simi1ar to that of the U.S. population. This risk coefficient was further adjusted for various values of the equilibrium factor.

Three expressions for health risk were employed. One is a lifetime cancer risk per individual for gamma exposure and lifetime lung cancer risk for radon daughter exposure. The second measure is the percent increase in cancer or lung cancer relative to the individual's normal cancer or lung cancer risk. The latter is obtained by dividing the probability of death from cancer or lung cancer as a result of the radiation exposure incurred during occupancy of the property by the population lifetime risk of mortality for the corresponding disease category. Finally, the number of projected excess cancer deaths due to the radiation exposure was calculated for each property as the sum of risks due to 
gamma-ray exposure, radon daughters and, for the single family residences, ingestion of food products for the total number of occupants. The number of projected cancer deaths can then be related to the cost of cleanup, thereby establishing a cost-benefit basis for assigning priorities for remedial action on various properties.

In calculating excess cancer deaths, occupancy data for many properties were abtained fromil the state of Utah Department of Health during $F Y$ 1983. These data were more reliable than those previously available to us and permitted a better estimate of projected cancer deaths for individual properties. If the pattern of occupancy is included in the development of estimates of projected cancer deaths, the estimates become more realistic in reflecting the variation of exposure levels that do in fact occur within many properties.

In accordance with a task assigned to the project by our oos sponsor, recommendations for modification of radiological survey protocols were developed. These were directed to improvement of the data base for calculating estimated health effects. The suggestions included improvement in the quality of occupancy data, including the typical distribution of persons within buildings; the simultaneous grab measurement of radon gas and daughters so that equilibrium factors could be estimated; and the use of distributed track-etch devices for radon gas measurement so that the pattern of exposure levels within different areas of the building could be more accurately characterized.

The report of methods and procedures previously submitted to oos was finalized. It included a summary description of procedures used in the project with detailed appendices relating to environmental pathway calculations, the scientific basis for the radon daughter exposure risk coefficients, and the procedure for selection of radon gas or daughter grab or integrated values in calculating health effects.

Finally, we participated in a Technical Measurements Center Workshop in Graind Junction, Colorado, to help develop the survey protocols employed by DOE radiological survey contractors for estimation of indoor radon and radon daughter concentrations. 


\section{- Liquefied Gaseous Fuels (LGF) Safety Studies}

The LGF Safety Studies project, started in FY 1977 with work on liquefied natural gas (LNG), was completed at the end of FY 1982. Objectives of this project were (1) to conduct research on LGF release prevention and control in support of DOE's LGF Safety and Environmental Control Assessment Program, and (2) to provide assistance to DOE in the planning, implementation, and technical surveillance of it's Program.

\section{LGF SPILL TEST FACILITY}

J. G. DeSteese

Though the LGF Safety Studies Project was conpleted at the end of FY 1982, PNL responded to a request from Headquarters to help complete a report. In March 1983, the House Appropriations Subcomittee on Energy and Water Development asked the DOE Assistant Secretary for Environmental Protection, Safety and Emergency Preparedness to prepare a report on the proposed Spill Test Facility for hazardous chemicals and liquefied gaseous fuels. PNL staff provided the executive summary and introduction sections together with the comprehensive appendix of background detail and the bibliography in the report DOE submitted to Congres5. This report was entitled Construction and Operation of a Liquefied Gaseous Fuels Spill Test Facility (DOE/EP-0094). PNL aTso participated in the activities of the report preparation committee and assisted in the review and editing of sections provided by other contributors. 



\section{- Environmental Protection Support and Assistance}

The Pacific Northwest Laboratory continued to provide technical assistance to DOE's Office of Operational Safety (OOS) in the area of environmental protection. PNL's technical support included extensive assistance in planning and conducting the fourth DOE Environmental Protection information Meeting and assisting in the review of proposed Clean Air Act emission standards for radionuclides. The Guide for Effluent Radiological Measurements at DOE Installations was completed and published, and work was started on the new environmental radiological surveillance guide. A report summarizing the radioactive effluents from DOE facilities was prepared.

ENIVIRONMENTAL PROTECTION SUPPORT AND ASSISTANCE TO DOE $/ 00 \mathrm{~S}$

J. P. Corley, C. D. Corbit, P. A. Eddy,

C. J. English, K. A. Hawley, R. E. Jaquish,

I. C. Nelson, L. S. Prater, l. K. Soldat,

J. R. Raymond, D. G. Watson, E. C. Watson

The Environmental Protection Support and A5sistance program provides the Department of Energy's Office of Operational Safety with technical support to assist oos in accomplishing its environmental protection objectives. Several tasks are funded concurrently, at the request of $00 \mathrm{~S}$, to provide flexibility in response to management priorities as they evolve. Task areas addressed during 1983 included:

- completion and publication of a guide for effluent measurements at DoE facilities

- evaluation of the DOE Quality Assessment Program through a workshop and review of results submitted by participants

- review of environmental dose modeling methods at DOE facilities

- summation of environmental report information from DoE nuclear facilities

- continued development of reporting systems for management of environmental program information

- assessment of need for tracking DoE commitments made in environmental impact statements

- initial development of guidelines and nodel program for ground-water monitoring at DOE facilities

- assistance to Oos in organizing and conducting the Fourth DOE Environmentai Protection Information Meeting

- review of emission standards proposed for radionuclides under the Clean Air Act.
EFFLUENT AND ENVIRONMENTAL MONITORING GUIDES

J. P. Corley

The environmental monitoring guide, a companion document to the effluent guide, is in the process of being revised and updated. This guide was written to promote greater uniformity in DOE environmental radiological monitoring programs.

OUALITY ASSURANCE REYIEW ANO RECOHMENDATIONS

R. E. Jaquish

PNL's support to the DOE Quality Assessment Program continued with a review of the activities and facilities of the Environmental Measurements Laboratory in New York. A Quality Assurance Workshop was organized and conduct. ed; a summary of the workshop was prepared and distributed to participants. The results of interTaboratory participation in sample analys is were reviewed, and statistical analysis of the data was provided to the Steering Committee.

ENVIRONMENTAL DOSE MODELING REVIEW

J. P. Corley

This task reviews the computer codes and models DOE facilities use to predict radiation doses to the public. A panel on environmental dose modeling has been established, selecting experienced individuals from throughout DOE. Members are currently reviewing the methods of dose modeling in use and will provide comments and recommendations early in FY 1984 .

SUMMARY OF ENVIRONMENTAL. REPORTS

\section{K. A. Hawley}

Each year, PNL provides for DOE management a summary of the information contained in the annual environmental reports generated by the DOE nuclear facility contractors. The 1981 report was published this summer; the 1982 
report (based on contractor documents received in May of 1983) was distributed to the sites for comment.

REPORTING SYSTEMS FOR ENVIRONMENTAL INFORMATION

R. E. Jaquish

A prototype systen designed to manage information on environmental programs at DOE facilities has been developed for the office of operational Safety. The system, which has several components, will manage information on the scope of environmental programs and on the status of their compliance with various environmental regulations.

FOLLOW-UP TO ENVIRONMENTAL IMPACT STATEMENT COMMITMENTS

I. C. Ne1son

A method was developed to select and track commitments made in DOE Environmental Impact Statements. A level of effort for this "EIS Follow-Up" was drafted for DOE management to consider, and a paper on the feasibility of such a program was presented at the DOE Environmental Protection Information Meeting. The task was closed in July.

GROUND-WATER MONITORING

P. A. Eddy, J. R, Raymond

A draft guideline of ground-water monitoring programs for DOE facilities was provided to DOE/OOS for review along with a model program. DOE Orders were reviewed for the ir ground-water program requirements, and FY1984 activities were developed in consultation with DOE/OOS staff.

DOE ENVIRONMENTAL PROTECTION INFORMATION MEETING

3. P. Corley

Arrangements for the Fourth DOE Environmental Protection Information Meeting were made.

PNL staff provided administrative support during and after the meeting. The proceedings, edited and organized by PNL, were published by DOE this surmer.

\section{SPECIAL ASSISTANCE}

R. E. Jaquish

This special assistance task provides quick responses to issues that fall outside the scope of the other established support programs. Technical support is given on an ad hoc basis as requested. During 1983, the activities conducted under this task included providing support to oos staff by reviewing emission standards proposed for radionuclides under the Clear Air Act, reviewing changes suggested for 10 CFR 20, and examining the reporting requirements specified in DOE order 5484.1A. 


\section{Publications and Presentations}


' 


\section{PUBLICATIONS}

Brackenbush, L. W., and W. Quam. 1983. "Hydrogenous Sericonductor Neutron Detectors." PNL-SA-11461. Phys. Rev. Letters.

Braumlich, P. W., et al. (In press). "Development of a Laser-Heated TLD Reader." In Proceedings of the International Beta Dosimetry Sympos ium.

Card, C. J., et al. 1983. "Current Practices in Beta Dosimetry at DOE Facilities." Health Phys. 45:224 (Abstract).

Eddy, P. A., and L. S. Prater. 1982. Summary Report of Ground-Water Monitoring Practices at Department of Energy Facilities. PNL-4251, Pacific Northiwest Laboratory, Richland, Washington.

Faust, L. G., and D. E. Hadlock. 1983. DOE Personnel Neutron Dosimeter Evaluation and Upgrade Progran, fY-1982 Program Report. PNL-4781. Pacific Northwest Laboratory, Richland, Washington.

Fisher, D. R., A. V. Robinson and R. T. Hadley. (In press). "Preliminary Results of Testing Bioassay Analytical Performance Standards." PNL-SA-11656. In Proceedings of the Eleventh Water Reactor Safety Research Information Meeting, Gaithersburg, Maryland.

Griffith, R. V., and T. McMahon. 1983, Development of a Personnel Neutron Dosimeter/Spectrometer, DOSPEC. Lawrence Livermore National Laboratory, Livermore, California.

Hadlock, D. E., L. G. Faust and E. J. Vallario. 1983. "Advances in Personnel Neutron Dosimetry." Health Physics Society Newsletter, Parts $1,2,3$. PNL-SA-11464, Pacific Northwest. Laboratory, Richland, Washingten.

Huang, S. J., and J. F. Johnson. 1982. Characterization and Control of a Model CR-39 PoTymer. Institute of Material Science, Jriversity of Connecticut.

Hurst, S. 1982. Resonarce Ionization Spectroscopy Feasibility Study, Final Report. Atom Sciences, Inc., Oak Ridge, Teminessee.

McDonald, J. C., et a?. 1983. Response Characteristics of Selected PersonneT Neutron Dosineters. PNL-398?, Pacific Northwest Laboratory, Richtand, Washington.

Murphy, D. W., et al. 1983. "Beta Measurement Evaluation and Upgrade Program." Health Phys. 45:216 (Abstract).

Parkhurst, M. A. 1982. Ninth DOE Workshop on Personnel Neutron Dosinetry. (Proceedings) CONF-820668. PNL-SA-10714, Pacific Northwest Laboratory, Richland, Washington.
Parkhurst, M. A. (In press). Tenth International Neutron Dosimetry Workshop. Pacific Northwest Laboratory, Richland, Washington.

Price, P. B., and G. Tarle. 198?. Development of Plastic Track Detectors for

Dosimetric Application, Final Report for Fy-1982. University of California at Berkeley.

Roberson, P. L., et al. 1983. Perfornance Comparison of Selected Personnel Dosimetry Systems in Use at Department of Energy Facilities. PNL-3983, Pacific Northwest Laboratory, Richland, Washington.

Roberson, P. L., et al. 1983. Guidelines for the Calibration of Personnel Dosimeters. PNL-4515, Pacific Northwest Laboratory, Richland, Washington.

Roberson, P. L., et al. 1983. Facilities and Procedures Used for the Performance Testing of DoE Personnel Dosimetry System. PNL 4207, Pacific Northwest Laboratory, Richland, Washington.

Robinson, A. V., D. R. Fisher and R. T. Hadley. 1983. "Results of Round One Testing of Draft ANSI Standard N13.30 'Performance Criteria for Radiobioassay'." PNL-SA-11543. In Proceedings of the Twenty-Ninth Annual Conference on Bioassay, Analytical and Environmental Chemistry, Seattle, washington.

Scherpelz, R. I., et al. 1983. "A Passive Multielement Pota Dosimeter." Health Phys. 45:206 (Abstract).

Selby, J. M., et al. (In press). "Field Measurement and Interpretation of Beta Doses and Dose Rates." PNL-SA-11106. In Proceedings of the International Beta Dosimetry Symposium.

Simons, G, G., et al. (In press). "Application of Beta Spectroscopy to Beta Dosimetry Research." In Proceedings of the International Beta Dosimetry Symposium.

U.5. Department of Energy. 1982. Summary of Annual Envirommental Reports for Cy 1981: Departrent of Energy Nuclear Sites.

$\overline{D O F} / \mathrm{EP}-0038 / 1$, U.S. DOE, Washington, D.C.

U.S. Department of Energv. 1983. Proccedinas of the Fourth DOE Envircmental Protection Information Meeting. CONF-83.1215, U.S. DOE, Washington, D.C.

U.S. Department of Energy. 1983. A Guide for Effluent Radiological Measurements at DOE InstaTations. DOE/EP-0096, 1.5. DOE, Washington, D.C. 



\section{PRESENTATIONS}

Brackenbush, L. W., et al. 1983. "A Mixed Field (Neutron and Gamma) Dose Equivalent Measuring Instrument." PNL-SA 11686. Presented at 10th D0E Personnel Neutron Dosimetry workshop. Acapulco, Mexico, August 29 to Septemr ber $2,1983$.

Brackenbush, L. W., et al. 1983. "A Method to Improve the Evaluation of a Combination Track Etch Dosimeter/Spectrometer." Paper presented at the 12th International Conference on Solid State Nuclear Track Detectors, September 5+9, 1983, Acapulco, Mexico.

Corley, J. P., and R. E. Jaquish. 1982. "PNL's Environmental Protection Support for the 0ffice of Operational Safety." Paper presented at the 4th DOE Environmental Protection Information Meeting, December 7-9, 1982, Denver, Coloradn.

Fisher, D, R., A. V. Robinson and R. T. Hadley. 1983. "Preliminary Results of Testing Bioassay Analytical Performance Standards." PNL-SA-11656. Eleventh water Reactor Safety Research Information Meeting, October 24-28, 1983. Gaithersburg, Maryland.

Kathren, R. L., et al. 1983. "Evaluation of a Draft Standard on Performance Specifications for Health Physics Instrumentation - Program Overview." PNL-SA 11072. Paper presented at the $28 \mathrm{th}$ Annual Health Physics Society Meeting, June 1983, Baltimore, MO.

Kenoyer, J. L., et al. 1983. "Evaluation of a Draft Standard on Performance Specifications for Health Physics Instrumentation - Initial Results for Environmental Tests." Paper presented at the 28th Annual Health Physics Society Meeting, June 1983, Baltimore, MD.

Neison, I. C., et al. 1982, "Feasibility of an EIS Follow-Up Program." Paper presented at the 4th DOE Environmental Protection Information Meeting, December 7-9, 1982, Denver, Colorado.

Roberson, P. L., et al. 1983. "Testing of Photon Energy Dependence for Health Physics Instrumentation." PNL-SA 11068. Paper presented at the 28th Annual Health Physics Society Meeting, June 1983, Baltimore, MO.

Robinson, A. V., D. R. Fisher and R. T. Hadley. 1983. "Results of Round One Testing of Draft ANSI Standard N13.30 'Perfomance Testing for Radiobioassay.'" PNL-SA-11543. Twenty-Ninth Annual Conference on Bioassay, Analytical and Environmental Chemistry, october 12-13, 1983. Seattle, Washington.

Selby, J. M., et al. 1983. "Field Measurement and Interpretation of Beta Doses and Dose Rates." PNL-SA 11106. Paper presented at the Beta Workshop, February 1983, Gaithersburg, MD.

Swinth, K. L., et al. 1983. "Evaluation of a Draft Standard on Performance Specifications for Health Physics Instrumentation - Initial Results for Radiological Tests." Paper presented at the 28th Annual Health Physics Society Meeting, June 1983, Baltimore, MD.

Swinth, K. L., et a1. 1983. "Performance Specifications for Health Physics Instrumentation." Paper presented at the Ionizing Radiation Measurements Workshop, September 1983, Park City, UT.

Welty, C. G., et al. 1983. "Radioactive Emissions and Radiation Exposure from U. S. Department of Energy Operations." Paper presented at the International Atomic Energy Agency International Conference on Radioactive Waste Management, May 16-20, 1983, Seattle, Washington. 



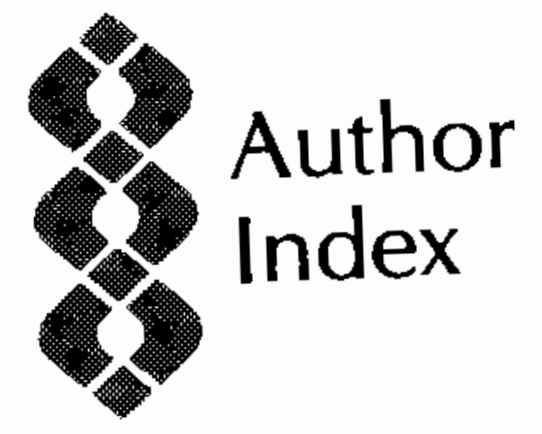





\section{AUTHOR INDEX}

Bair, W. J.; 19

Brackenbush, L. W.; 7, 11

Carbaugh, E. H.; 3

Corbit, C. D.; 25

Corley, J. P.; 5, 25, 26

Cross, F. T.; 21

Denham, D. H.; 21

DeSteese, J. G.; 23

Eddy, P. A.; 25, 26

Endres, G. W. R.; 11

English, C. J.; 25

Faust, L. G.; 11

Fisher, D. R.; 2, 3

Fox, R. A.; 9

Gillings, J. C.; 4, 5
Hadley, R. T.; 2

Hadlock, D. E.; 11

Haggard, D. L.; 11

Hawley, K. A.; 25

Heid, K. R.; 3, 5

Herrington, W. N.; 5

Higby, D. P.; 3, 5

Hooker, C. D.; 4, 9

Jaquish, R. E.; 25, 26

Kathren, R. L.; 1, 4, 5

Kennedy, W. E. Jr.; 21

Kenoyer, J. L.; 1

Marks, S.; 21

McDonald, J. C.; 7, 9, 10, 11

Munson, L. H.; 5

Murphy, B. L.; 3, 4, 5

Murphy, D. W.; 4, 13
Nelson, I. C.; 25, 26

Pappin, J. L.; 9

Parkhurst, M. A.; 11

Pisarick, J. M.; 5

Prater, L. S.; 25

Rathbun, L. A.; 13

Raymond, J. R.; 25, 26

Roberson, P. L.; 4, 9, 13

Robinson, A. V.; 2, 5

Scherpelz, R. I.; 6

Selby, J. M.; 4, 5

Soldat, J. K.; 25

Swinth, K. L.; 1, 5, 9, 10, 13

Traub, R. J.; 3

Watson, D. G.; 25

Watson, E. C.; 25 


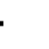


Organization Charts

Distribution 



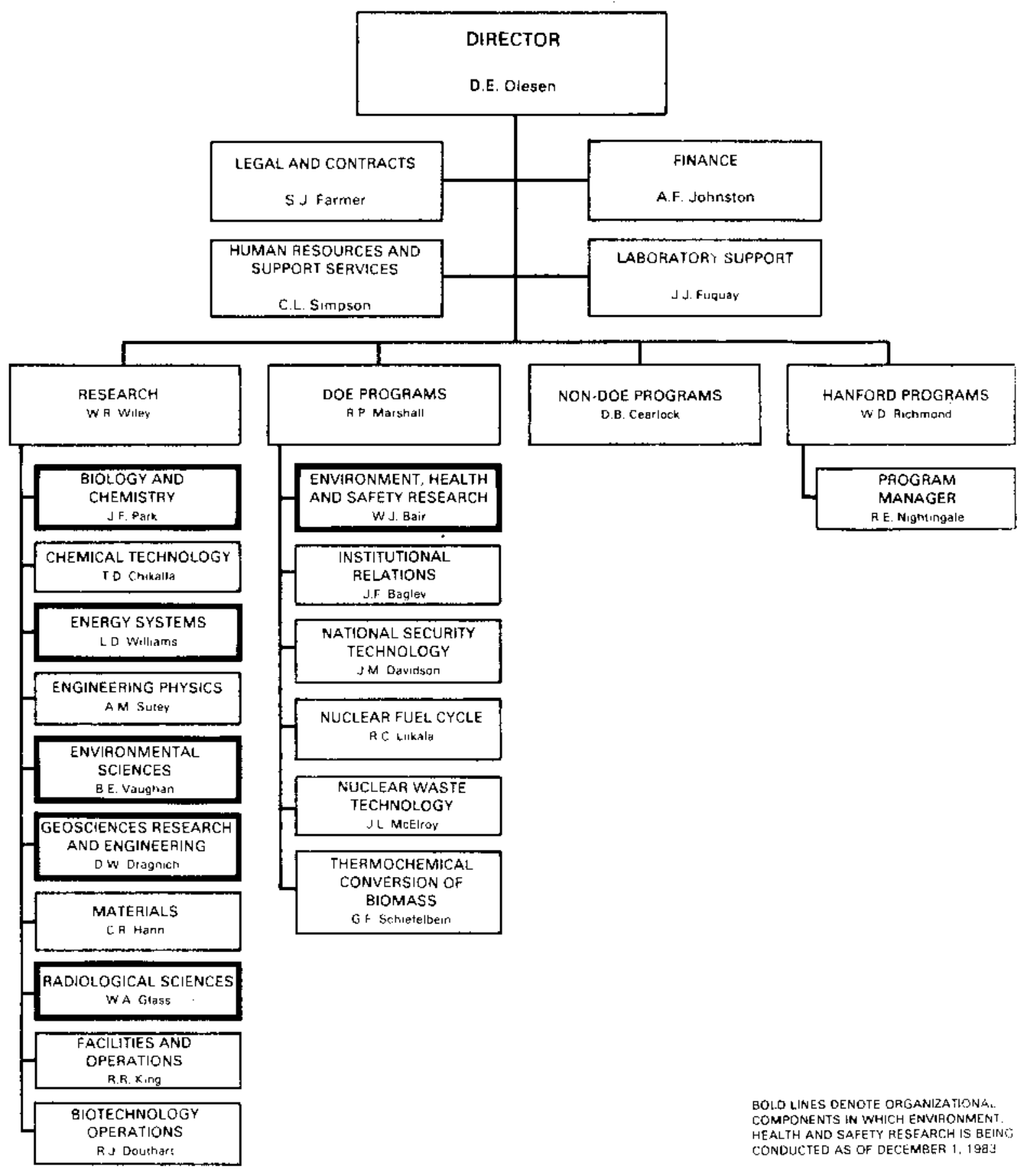




\section{ENVIRONMENT, HEALTH AND SAFETY RESEARCH}

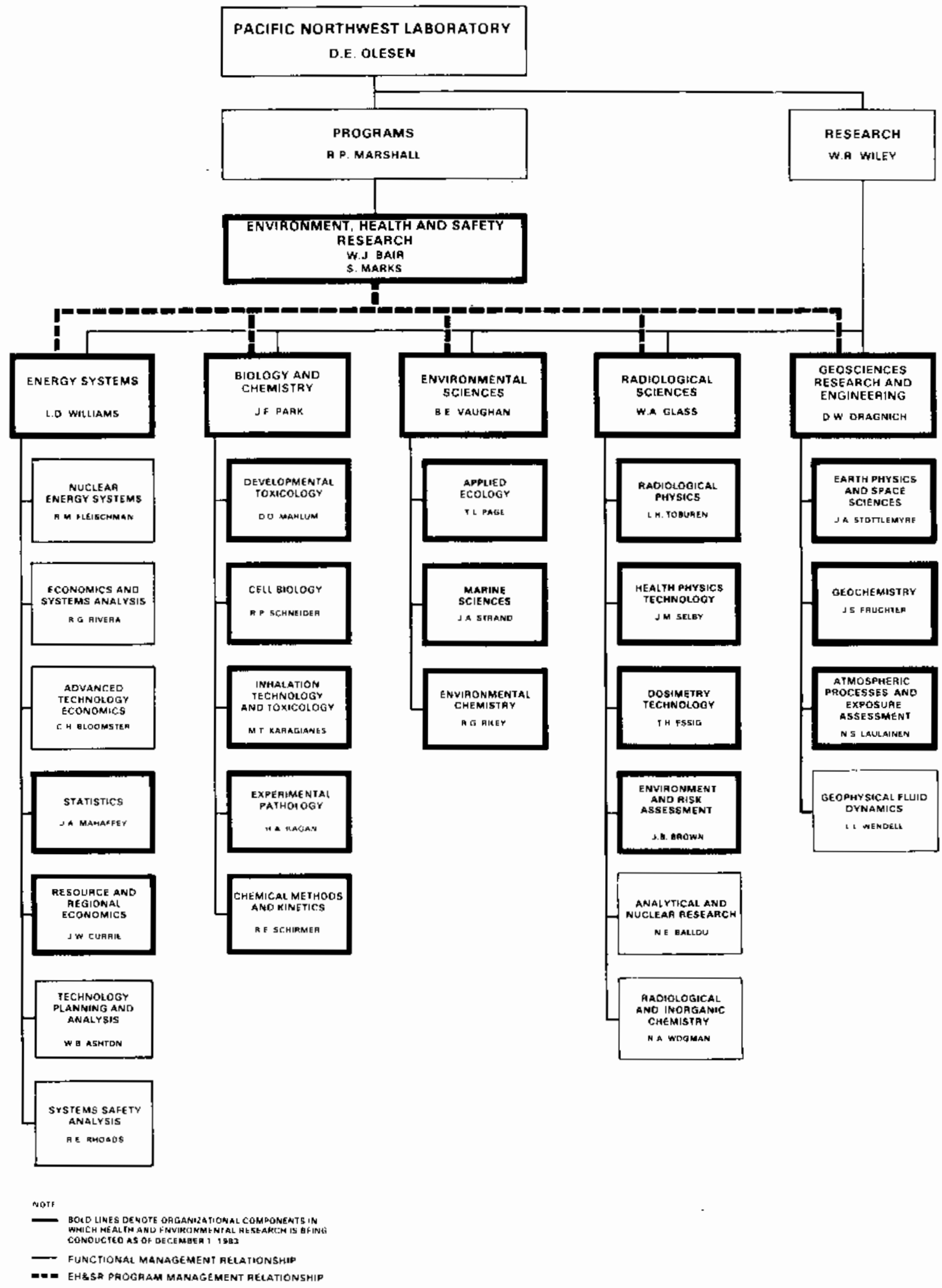




\section{DISTRIBUTION}

No. of

Copies

\section{OFFSITE}

W. R. Albers

Office of Operational

Safety

Office of Coal Processing

Office of Fossil Energy

Department of Energy

$\mathrm{FE}-43, \mathrm{GTN}$

Germantown, MD 20545

D. Ballantine

Office of Health and

Environmental Research

office of Energy Research

Department of Energy

ER-74, GTN

Germantown, MD 20545

R. W. Barber

Office of Nuclear Safety

Office for Environmental

Protection, Safety \&

Emergency Preparedness

Department of Energy

EP-341, GTN

Germantown, MD 20545

N. F. Barr

Office of Health and

Environmental Research

office of Energy Research

Department of Energy

ER-73, GTN

Germantown, MD 20545

R. W. Beadle

Office of Health and

Environmental Research

Office of Energy Research

Department of Energy

ER-74, GTN

Germantown, MD 20545

J. R. Beall

Office of health and

Environmental Research

Office of Energy Research

Department of Energy

ER-72, GTN

Germantown, MD 20545

R. P. Blaunstein

Office of Nuclear Safety

Office for Environmental

Protection, Safety \&

Emergency Preparedness

Department of Energy

EP-34, GTN

Germantown, 20545
No. of

Copies

L. C. Brazely, Jr.

office of Operational

Safety

Office for Environmental

Protection, Safety \&

Emergency Preparedness

Department of Energy

EP-32, GTN

Germantown, MD 20545

P. Buhl

Office of Coal Processing

Office of Fossil Energy

Department of Energy

FE-43, GTN

Germantown, MD 20545

P. Cho

Office of Health and

Environmental Research

Office of Energy Research

Department of Energy

ER-73, GTN

Germantown, MD 20545

D. W. Cole, Jr.

Office of Health and

Environmental Research

Office of Energy Research

Department of Energy

ER-73, GTN

Germantown, MD 20545

R. H. Davies

Office for Environmental

Protection. Safety \&

Emergency Preparedness

Department of Energy

$E P-30$, FORR

Washington, DC 20585

L. J. Deal

Office of Nuclear Safety

Office for Environmental

Protection, Safety \&

Emergency Preparedness

bepartment of Energy

EP -34, GTN

Germantown, MD 20545

J. Dorigan

Office of Health \&

Environmental Research

Office of Energy Research

Department of Energy

ER-75, GTN

Germantown, MD 20545
No. of

Copies

G. D. Duda

Office of Health \&

Environinental Research

office of Energy Research

Department of Energy

ER-72, GTN

Germantown, MD $20545^{\circ}$

A. P. Duhame 1

Office of Health \&

Environmental Research

0 ffice of Energy Research

Department of Energy

ER-74, GTN

Germantown, M[ 20545

C.W. Edington

Office of Health \&

Environmental Research

office of Energy Research

Department of Energy

ER-70, GTN

Germantown, MD 20545

J. E, Fitzgerald, Jr.

Office of Operational

Safety

Office for Environmental

Protection, Safety \&

Emergency Preparedness

Department of Energy

$E P-342$, GTN

Germantown, MD 20545

W. 0. Forster

0 ffice of Health \&

Environmental Research

Office of Energy Research

Department of Energy

ER-75, GTN

Germantown, MD 20545

T. G. Frangos

Office of Operational Safety

Office for Environmental Protection, Safety

Emergency Preparedness

Department of Energy

EP-321, GTN

Germantown, MD 20545

R. E. Franklin

Office of Health \&

Environmental Research

Office of Energy Research

Department of Energy

ER-75, GTN

Germantown, MD 20545 
No. of

Copies

R. Goldsmith

Office of Health \&

Environmental Research

Office of Energy Research

Department of Energy

ER-73, GTN

Germantown, MD 20545

G. Goldstein

Office of Health \&

Environmental Research

Office of Energy Research

Department of Energy

ER-74, GTN

Germantown, MD 20545

D. H. Hamilton, Jr.

Office of Health \&

Environmental Research

Office of Energy Research

Department of Energy

ER-75, GTN

Germantown, MD 20545

H. Hollister

Office of Deputy Assistant Secretary

Office for Environmental

Protection, Safety \&

Emergency Preparedness

Departiment of Energy

EP-30, FORR

Washington, DC 20585

F.P. Huds on

Office of Health \&

Environmental Research

Office of Energy Research

Departinent of Energy

ER-74, GTN

Germantown, MD 20545

G. Y. Jordy

Office of Program Analysis

Office of Energy Research

Department of Energy

$F R-30, G T N$

Germantown, MD 20545

J, S. Kane

Office of Energy Research

Department of Energy

ER-2, FORR

Washington, DC 20585

J. Kaufman

Office of Program Analysis

Office of Energy Research

Department of Energy

ER-31, GTN

Germantown, MD 20545
No. of

Copies

W. J. Little, Jr.

Office of Deputy Assistant Secretary

Office for Environmental

Protection, Safety \&

Emergency Preparedness

Department of Energy

EP-30, FORR

Washington, OC 20585

J. N. Maddox

Office of Health \&

Environmental Research

Office of Energy Research

Department of Energy

ER-73, GTN

Germantown, MD 20545

J. R. Maher

Office of Nuclear Safety

office for Environmental

Protection, Safety \&

Emergency Preparedness

Department of Energy

EP-34, GTN

Germantown, MO 20545

C. R. Mandelbaum

Office of Program Analysis

Office of Energy Research

Department of Energy

ER-32, GTN

Germantown, MD 20545

S. Mathur

Office of Operational Safety

0 fice for Environmental

Protection, Safety \&

Emergency Preparedness

Departiment of Energy

EP-321, GTN

Germantowm, MD 20545

0. 0. Mayhew

Office of Management

Office of Energy Research

Department of Energy

ER-63, GTN

Germantown, MD 20545

H. M. McCammon

Office of Health \&

Environmental Research

Office of Energy Research

Department of Energy

ER-75, GTN

Germantown, MD 20545
No. of

Copies

T. F. McCraw

Office of Operational

Safety

Office for Environmental

Protection, Safety \&

Emergency Preparedness

Department of Energy

EP-32, GiN

Germantawn, MD 20545

M. L. Minthorn, Jr.

Office of Health \&

Environmental Research

Office of Energy Research

Department of Energy

ER-72, GTN

Germantown, MD 20545

D. R. Mont $i$

Office of Quality

Assurance and

Standards

Office for Environmental

Protection, Safety \&

Emergency Preparedness

Department of Energy

EP-35, GTN

Germantown, MD 20545

D. 0. Moses

Office of Environmental

Analysis

Office for Environmental

Protection, Safety \&

Emergency Preparedness

Department of Energy

EP-332, GTN

Germantown, MD 20545

H. Moses

Office of Health \&

Environmental Research

Office of Energy Research

ER-74, GTN

Germantown, MO 20545

H. E. Mott

Office of Operational Safety

Office for Environmental Protection, Safety \&

Emergency Preparedness

Department of Energy

EP-323, GTN

Germantown, MO 20545 
No. of

Copies

W. S. Osburn, Jr.

Office of Health \&

Environmental Research

Office of Energy Research

Department of Energy

ER-75, GTN

Germantown, MD 20545

C. L. Osterberg

Office of Health \&

Environmental Research

office of Energy Research

Department of Energy

ER-75, GTN

Germantown, MO 20545

D. E. Patterson

Office of Operational

Safety

Office for Environmental

Pratection, Safety \&

Emergency Preparedness

Department of Energy

EP-32, GTN

Germantown, MO 20545

R. G. Rader

Office of Program Analysis

Office of Energy Research

Department of Energy

$E R-32$, GTN

Germantown, MD 20545

S. Rose

Office of Health \&

Enviromental Research

Office of Energy Research

Department of Energy

ER-73, GTN

Germantown, MD 20545

D. M. Ross

Office of Operationa

Safety

Office for Environmental Protection, Safety \&

Emergency Preparedness

Department of Energy

EP-321, GTN

Germantown, MD 20545

G. J. Rotariu

Office of Nuclear Safety

Office for Environmental Protection, Safety \&

Emergency Preparedness

Department of Energy

EP-342, GTN

Germantown, MD 20545
No, of

Copies

G. W. Saunders, Jr.

Office of Health \&

Environmental Research

Office of Energy Research

Departmenf of Energy

ER-75, GTN

Germantown, MD 20545

M. Schulman

Office of Health

Environmental Research

Office of Energy Research

Department of Energy

ER-70, GTN

Germantown, MD 20545

R. D. Shull

Office of Environmental

Analys is

Office for Environmental

Protection, Safety 8

Emergency Preparedness

Department of Energy

EP-33, GTN

Germantown, MD 20545

D. R. Slade

Office of Health \&

Environmental Research

Office of Energy Research

Department of Energy

ER-74, GTN

Gerinantown, MD 20545

D. A. Snith

Office of Health \&

Environmental Research

Office of Energy Research

Department of Energy

ER-72, GTN

Germantown, MD 20545

1. Snow

Office of Energy Research

Department of Energy

ER-6, FORR

Washingtnn, DC 20585

G. E. Stapleton

Office of Health \&

Environmental Research

Office of Energy Research

Department of Energy

ER-72, GTN

Germantown, MD 20545
No. of

Copies

\author{
R. J. Stern \\ Office of Environmental \\ Compliance \\ Office for Environmenta? \\ Protection, Safety \& \\ Emergency Preparedness \\ Department of Energy \\ EP-36, FORR \\ Washington, DC 20585 \\ L. Swinebroad \\ Office of Program Control \\ Staff \\ Office for Environmental \\ Protection, Safety \& \\ Emergency Preparedness \\ Department of Energy \\ $E P-30.1$, GTK \\ Germantown, MD 20545 \\ J. W. Thiessen \\ Office of Health \& \\ Environmental Research \\ Office of Energy Research \\ Department of Energy \\ ER-71, GTN \\ Germantown, MD 20545 \\ A. Trivelpiece \\ Director \\ Office of Energy Research \\ Department of Energy \\ ER-1, FORR \\ Washington, DC 20585 \\ E. U. Vallario \\ Office of Nuclear Safety \\ Office for Environmental \\ Protection, Safety \& \\ Emergency Preparedness \\ Department of Energy \\ EP-342, GTN \\ Germantown, MD 20545 \\ W. A. Vaughan \\ Assistant Secretary for \\ Environmenta\} Protection, \\ Safety \& Emergency \\ Preparedness \\ Department of Energy \\ EP-1, FORR \\ Washington, DC 20585 \\ R. L. Watters \\ Office of Heaith \& \\ Environmental Research \\ Office of Energy \\ Research \\ Department of Energy \\ ER-75, GTN \\ Germantown, MD 20545
}


No. of

Copies

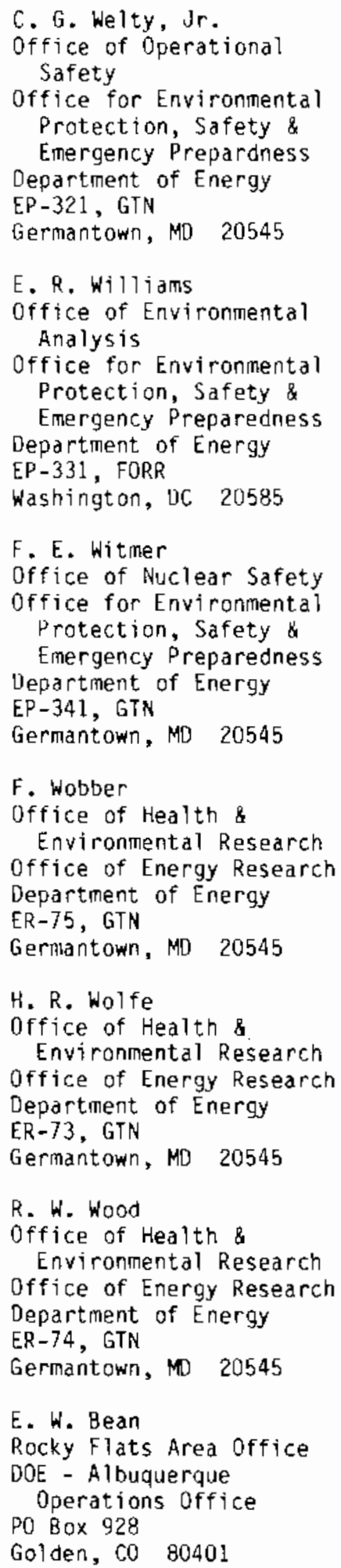

No. of

Copies

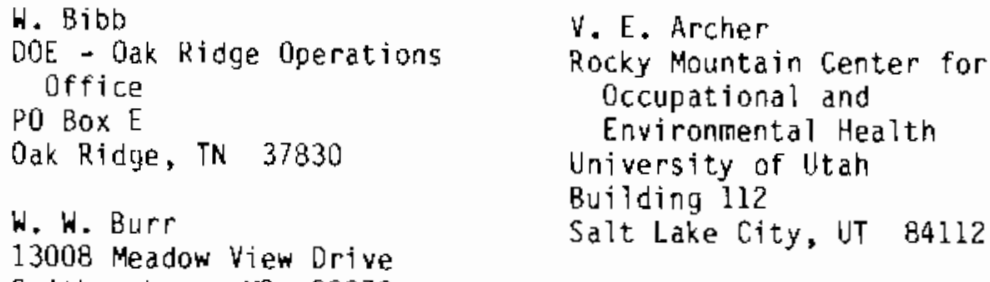

\author{
V. E. Archer \\ Rocky Mountain Center for \\ Occupational and \\ Environmental Health \\ University of Utah \\ Building 112 \\ Salt Lake City, UT 84112
}

G. P. Dix

26619 Haney Avenue

Damascus, MD 20750

D. M. Gardiner

DOE - Chicago Operations Office

9800 South Cass Avenue

Argonne, IL 60439

D. S. Ingle

Dayton Area Office

DOE - Albuquerque Operations office

P0 Box 66

Miamisburg, OH 45342

R. Nelson

DOE - Nevada Operations Office

PO Box 14100

Las Vegas, NV 89114

R. Ray

DOE - Nevada Operations

Office

PO Box 14100

Las Vegas, NV 89114

J. R. Roeder

DOE - ATbuquerque Operations office

P0 Box 5400

Albuquerque, NM 87115

J. H. Spickard

OOE - Idaho Operations Commission

550 Second Street

Idaho Falls, ID 83401

M. M. Williamson

DOE - Idaho Operations Commission

550 Second Street

Idaho Falls, ID 83401

D. Anderson

Envirotest

2818 East Lake Sammanish $N$. Redmond, WA 98052
No. of

Copies

A. W. Decora

Laramie Energy Research

Center

Department of Energy

P0 Box 3395

Laranie, WY 83071

P. B. Dunaway

DOE - Oak Ridge Operations Office

PO Box E

Oak Ridge, TN 37830

B. M. Erickson

DOE - Schenectady Naval Reactors office

P0 Box 1069

Schenectady, NY 12301

G. H. Gronhovd

Grand Forks Energy

Research Center

Department of Energy

Box 8213

University Station

Grand Forks, ND 58202

C. Jackson

DOE - San Francisco Operations office

133 Broadway

Wells Fargo Building

Oakland, CA 94616

R. F. Kendall

Bartlesville Energy

Research Center

Department of Energy

P0 Box 1398

Bartlesville, OK 74003

B. Morgan

DOE - Sayannah River Operations office

PO Box A

Aiken, SC 29801

A. A. Pitrolo

Morgantown Energy Research Center

Department of Energy

P0 Box 880

Morgantown, WV 26505
University Station 
No. of

Copies

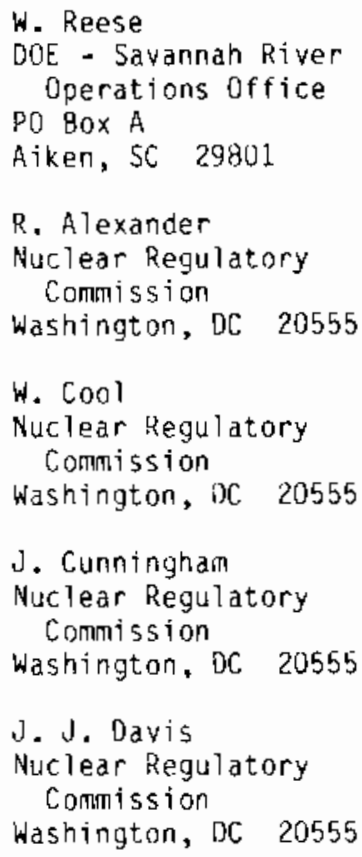

No. of

Copies

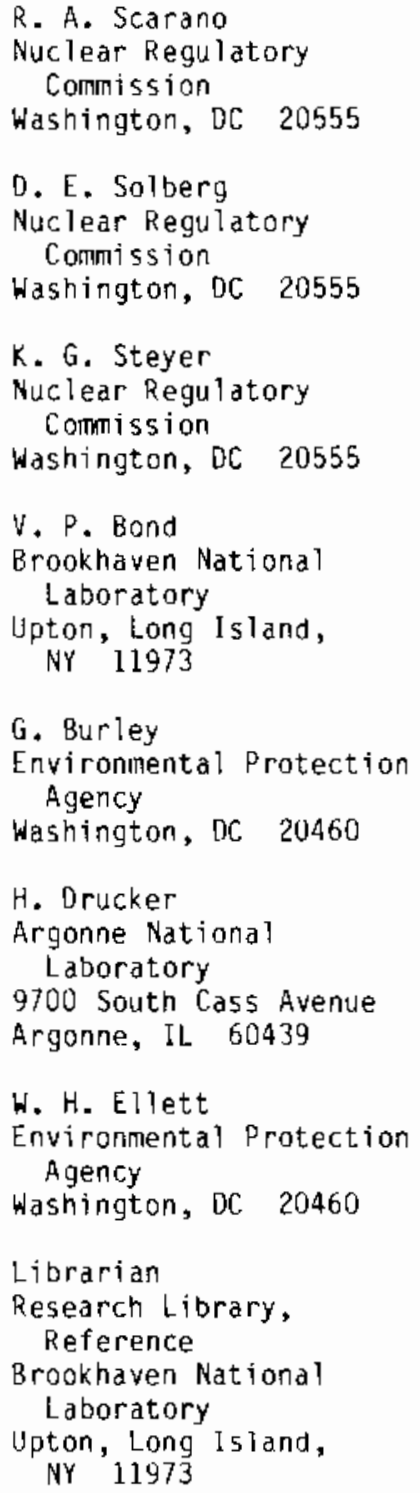

N. Nelson

Environmental Protection Agency

Washington, DC 20460

W. R. Ney

Executive Director

National Council on Radiation Protection and Measurements

7910 Woodmont Avenue

Suite 1016

Washington, DC 20014
No, of

Copies

A. Richardson

Environmental Protection Agency

washington, DC 20460

w. Sinclair

National Council on Radiation Protection and Measurements

7910 Woodmont Avenue Suite 1016

Washington, DC 20014

F. Swanberg

Nuclear Regulatory Commission

Washington, DC 20555

H. L. Volchok

Department of Energy

Environmental Measurements Laboratory

376 Hudson St.

New York, NY 10014

E. L. Alpert

Lawrence Berkeley Laboratory

University of California

Building 90, Room 2056

No. 1 Cyclotron Road

Berkeley, CA 94720

27 DOE Technical Information Center

R. Hall

Savannah River Laboratory

E. I. duPont de Nemours and Company

Aiken, SC 29801

R. M. Jefferson

Sandia Laboratories P0 Box 5800

Albuquerque, NM 87187

Librarian

Lawrence Radiation Laboratory

University of California Technical Information Department, L-3

P.0. Box 808

Livermore, CA 94500

C. B. Meinhold

Brookhaven National Laboratory

Upton, Long Island, NY 11973 
No. of Copies

M. L. Mendelsohn University of California

Lawrence Livermore National Laboratory

P.0. Box 808

Livermore, CA 94550

C. R. Richmond

Oak Ridge National

Laboratory

P0 Box $X$

Oak Ridge, TN 37830

Y. E. Ricker

Lawrence Livermore National Laboratory

P.0. Box 5507

Livermore, CA 94550

X. A. Smith

Sandia Laboratories

P0 Box 5800

Albuquerque, NM 87187

Technical Information Service

Room 773A

Savannah River Laboratory

E. I. dupont de Nemours and Company

Aiken, SC 29801

J. H. Birely

Los Alamos Scientific Laboratory

University of California

P.0. Box 1663

Los Alamos, NM 87545

R. Cat lin

Electric Power Research Institute

3412 Hillview Avenue

Palo Alto, CA 94304

J. W. Healy

Los Alamos Scientific Laboratory

University of California

P.0. Box 1663

Los Alamos, NM 87545

J. 0. Jackson

Los Alamos Scientific Laboratory

University of California

P.0. Box 1663

Los Alamos, NM 87545
No. of

Copies

R. Lunt

University of California

Center of Life Sciences

900 Veteran Avenue

West Los Angeles, CA 90024

\section{R. O. McClellan \\ Inhalation Toxicology Research Institute \\ Lovelace Foundation for Medical Education and Research \\ P.0. Box 5890}

Albuquerque, NM 87115

D. W. Moeller

Harvard School of Public

Health

Harvard University

Cambridge, MA 02138

D. Rall

NIEHS

P.0. Box 12233

Research Triangle Park, NC 27709

G. L. Voelz

Los Alamos Scientific Laboratory.

University of California

P.0. Box 1663

Los Alamos, NM 87545

W. Weyzen

Electric Power Research Institute

$3412 \mathrm{Hillview} \mathrm{Avenue}$

Palo Alto, CA 94304

D. Beirman

Chief, Document Service Branch

Central Intelligence Agency

Attn: CKS/DPSD/DSB/IAS/ $409779 / 0 B$

Washington, DC 20505

L. Bustad

College of Veterinary Medicine

Washington State University

Pullman, WA 99163

Council of Environmental Quality

72 Jackson Place, NW

Washington, DC 20006
No, of

Copies

\author{
Director \\ Commonwealth Scientific \\ and Industrial Research \\ Organization \\ Aspendal, Victoria, \\ AUSTRALIA \\ 0. Irwin \\ Librarian \\ Supervising Scientist for \\ the Alligator Rivers \\ Region \\ P.0. Box 387 \\ Bondi Junction 2022 \\ AUSTRALIA \\ Librarian \\ Joint Center for Graduate \\ Study \\ 100 Sprout Road \\ Richiand, WA 99352 \\ Librarian \\ Los Alamos Scientific \\ Laboratory \\ University of California \\ P.0. Box 1663 \\ Los Alamos, NM 87545 \\ J. W. McCaslin \\ INEL, Aerojet Nuclear \\ 550 Second Street \\ Idaho Falls, ID 83401 \\ M. E. Wrenn \\ University of Utah \\ Building 351 \\ Salt Lake City, UT 84112
}

R. E. Yoder

Rockwell International

P.0. Box 464

Golden, C0 80401

M. Anderson

Library

Department of National

Health and Welfare

ottowa, Ontario

CANADA

G. Cowper

Atomic Energy of Canada, Limited

Chalk River Nuclear

Laboratories

Chalk River, Ontario

KOJ IJO

CANADA 
No. of

Copies

Deng Zhicheng

North China Institute of Radiation Protection Taiyuan, Shanxi Province THE PEOPLE'S REPUBLIC OF CHINA

Zhu Zhixian

Laboratory for Energy-

Related Health

Research

University of California

Davis, CA 95616

A. M. Beau (Librarian)

Conmissariat à l'Energie Rtomique

Fontenay Rux Roses

FRANCE

Director

Commissariat à l'Energie Atomique

Centre d'Etudes

Nucléaires de Fontenayaux Roses

FRANCE

M. Fitoussi

Commissariat à l'Energie Atomique

Department de Protection

B.P. 6

$F-42260$ Fontenay aux Roses

FRANCE

Librarian

Centre d'Etudes

Nucléaires de Saclay

P.0. Box 2, Saclay

Fig-sur-Yvette $(50)$

FRANCE

Librarian

ENEA (OECD) Health and

Safety office

38 , Blvd. Suchet.

Paris,

FRANCE

J. C. Nenot

Commissariat à l'Energie

Atomique/SPS

BP 6/F92260

Fontenay-aux-Roses

FRANCE
No. of

Copies

J.P. Olivier

ENEA (OECD) Health and

Safety office

38, Blvd. Suchet

Paris,

FRANCE

M. Rzekiecki

Commissariat à l'Energie Atomique

Centre d'Etudes

Nucléaires de Cadarache

BP n 13-St. Paul

Les Durance

FRANCE

F. 0. Sowby

International Commission on Radiological protection

Clifton Avenue

Sutton, Surrey

ENGLAND

J. Booz

KFA Julich, Institute of Medicine

D-5170 Julich 1

Postfach 1913

FEDERAL REPUBLIC OF WEST GERMANY

L. Feinendegen

Director of Institute of Medicine

Institut fur Medizin

Kernforchung sanlage Julich

Postfach 1913

517 , Julich

FEDERAL REPUBL IC OF

WEST GERMANY

A. R. Gopal-Ayengar c/o Mr. P. K. Dayanidhi

15-D Gulmarg,

Anushakt inagar

Bombay-400 094

INDIA

W. Jacobi

Institut fur Strahlenschutz

0-8042 Neuherberg

Ingolstaddter

Landstrasse 1

FEDERAL REPUBLIC OF WEST GERMANY
No. of

Copies

H. J. Klimisch

BASF Aktiengesellschaft

Abteilung Toxikologie

6700 Ludwigshafen

FEUERAL REPUBLIC OF

WEST GERMANY

T. Kumatori

Director

National lnstitute of

Radiological Sciences

4-9-1, Anagawa

Chiba-shi, Chiba 260

JAPAN

H. G. Paretzke

GSF

D-8042 Neune!berg.

FEDERAL REPUIBLIC OF WEST GERMANY

V. Prodi

Department of Physics

University of Bologna

$\checkmark i a$ I minerio 46

I-40126 Bologna

ITALY

Professor Rotondi

CNEN CSN Cassacia

Casella Postale 2400

1-0100 Roma

ITALY

J. K. Basson

Vice-President

Raad Op Atomic

Atoomkrag Energy Board

Privaatsk $\times 256$

Pretoria 0001

REPUBLIC OF SOUTH AFRICA

Z. M. Beekman

President of IRPA

Rooseveltlaan 197

1079 AP Amsterdam

THE NETHERLANDS

A. Brink

Sasol-0ne Limited

P.O. Box 1

Sasolburg 9570

REPUBLIC OF SOUTH AFRICA

D. Djuric

Institute of Occupational Radiological Health

11000 Beograd

Deligradska 29,

YUGOSLAVIA 
No. of

Copies

$x$. E. Lennart Johansson

National Defense Research Institute

FOA 451

$S-901-82$

Umea,

SWEDEN

E. Komaroy

Environmental Health

Division

world Heaith Organization

Avenue Appia 1211

Geneva 27 ,

SWITZERLAND

M. J. Suess

Regional officer for

Environmental Hazards

World Health Organization

8 , Scherfigsvej

DK-2100

Copenhagen,

DENMARK

B. C. Winkler

Director, Licensing (Standards)

Raad op Atoomkrag/Atomic Energy Board

Privadsak $X 256$

Pretoria 0001

REPUBLIC OF SOUTH AFRICA

Deng Zhicheng

North China Institute of Radiation Protection

Taiyuan, Shanxi Province THE PEOPLE'S REPUBLIC OF CHINA

Zhu Zhixian

Laboratory for Energy. Related Health

Research

University of California

Davis, CA. 95616

Xie Zi

Senior Engineer

Scientific Secretary of

Radiation Protection

Laboratory

Institute of Atomic Energy

PO Box 275, Beijing

THE PEOPLE'S REPUBLIC OF CHINA
No. of

Copies

Pan 2i-qiang

Head of Health Physics Lab

Atomic Energy Institute

Beijing

THE PEOPLE'S REPUBLIC OF CHINA

ONSITE

3 DOE Kichland Operations office

H. E. Ransom/P. K. Clark

D. R. Elle

F. R. Standerfer

Rockwell Hanford

Operations

P. G. Lorenzini

2 Westinghouse Hanford Company

R. 0. Budd

D. E. Simpson

2 Hanford Environmental Health Foundation

B. D. Breitenstein

R. D. Gilmore

UNC Nuclear Industries

M. A. Payne

4 Battelle Columbus

A. H. Adeliman

A. D. Barker

D. N. Gideon

F. U. Milford

5 N. E. Carter

L. L. German

R. S, Paul

D. B. Shipler

L. R. Vest

2 Battelle WA, DC Office

G. Johnson

S. Stryker

9 Battelle-Seattle

F. A. Morris

S. M. Nealey

E. B. Perrin

W. L. Rankin

A. H. Schilling
No. of

Copies

Battelle-Seattle (contd)

C. R. Schuller

R. Shikiar

M. E. Walsh

M. T. Wood

136

Pacific Northwest Laboratory

R. W. Baalman (10)

W. J. Bair (20)

E. G. Baker

C. M. Berkowitz

H. J. Bomelburg

J. C. Bawer

L. W. Brackenbush

E. H. Carbaugh

T. D. Chikalla

E. D. Clayton

C. D. Corbit

J. P. Corley

C. E. Cowan

P. J. Cowley

F. T. Cross

J. M. Davidson

W. E. Davis

G. W. Dawson

D. E. Deonigi

D. H. Denham

J. G. DeSteese

D. A. Dingee

T. J. Doherty

P. A. Eddy

C. E. Elderkin

G. W. R. Endres

C. J. English, Jr.

S. J. Farmer

L. G. Faust

B. A. Fecht

D. R. Fisher

J. J. Fix

D. M. Fleming

R. A. Fox

A. L. Franklin

J. J. Fuquay

T. E. Gates

J. C. Gillings

W. A. Glass (5)

R. H. Gray

R. T. Hadley

D. E. Hadlock

D. L. Haggard

C. R. Hann

W. N. Harrington

K. A. Hawley

K. R. Heid

D. P. Higby

G. M. Holter

C. D. Hooker

R. E. Jaquish

R. L. Kathren 
No. of

Copies

Pacific Northwest Laboratory (contd)

W. E. Kennedy

J. L. Kenoyer

G. J. Konzek

H. V. Larson

R. C. Liikala

S. Marks

G. D. Marr

R. P. Marshall

J. C. McDonald

J. E. Mendel

J. E. Minor

L. H. Munson

B. L. Murphy

D. W. Murphy

I. C. Nelson

K. O. Nelson

$J$. M. Nielsen

R. E. Night ingale
No. of

Copies

Pacific Northwest Laboratory (contd)

D. E. Olesen

J. L. Pappin

M. A. Parkhurst

P. J. Pelto

A. M. Platt

T. D. Powers

L. S. Prater

L. A. Rathbun

J. R. Raymond

W. D. Richmond

T. B. Rideout

P. L. Roberson

A. V. Robinson

R. I. Scherpelz

G. F. Schiefelbein

L.C. Schmid

J. B. Schuette
No, of

Copies

Pacific Northwest

Laboratory (contd)

J. M. Selby

R. Snikiar

C. L. Simpson

J. K. Soldat

M. E. Stifter

$D$. L. Strenge

A. M. Sutey

K. L. Swinth

R. J. Traub

B. E. Vaughan

S. E. Vickerman

D. G. Watson

W. R. Wiley

L. D. Williams

K. M. Yasutake

5 Technical Information

2 Publishing Coordination 